\title{
Genel Kentsel Dönüşüm Alanları ile Öncelikli Riskli Alanlar Arasındaki İlişkinin Sorgulanması Üzerine Bir Değerlendirme: İstanbul Örneği
}

\author{
An Evaluation of the Relationship Between General Urban \\ Regeneration Areas and Priority Risk Areas: \\ The Case of Istanbul
}

\section{Yasin Bektaş}

Erciyes Üniversitesi Mimarlık Fakültesi, Şehir ve Bölge Planlama Bölümü, Kayseri

\section{ÖZ}

Kentsel dönüşüm olgusu, son yıllarda dünyanın birçok ülkesinde olduğu gibi Türkiye'de de "yeni kent politika"sının önemli bir unsuru olarak gündeme geldiği görülmektedir. Bu araştırmada, "afet riski, imar mevzuatına aykırıık, riskli yapı, zemin yapısı...” gibi gerekçelerle ilan edilen "genel kentsel dönüşüm alanları" ile gerçek durumda risk faktörü taşıyan "öncelikli riskli alanlar" arasındaki ilişkinin İstanbul örneğinde incelenmesi amaçlanmaktadır. Araştırmanın ilk aşamasında; İstanbul'da 5366, 5393, 6306 sayılı yasalar kapsamında ilan edilen tüm dönüşüm alanlarının niceliksel verileri (yasa, ilan yılı, büyüklüğü, mevcut durum bilgileri) Çevre ve Şehircilik Bakanlı̆̆ı, İstanbul Büyükşehir Belediyesi ve ilçe belediyelerinden talep edilmiştir. Dönüşüm alanlarıyla ilgili eksik bilgi ve belgeler daha sonra İstanbul Kentsel Dönüşüm Master Planı analiz verileri, internet üzerinden yapılan araştırmalar ve ilçe belediyeleriyle yapılan görüşmeler sonucunda tamamlanmıştır. İkinci aşamada, Japon Uluslararası İşbirliği Ajansı-JICA Afet Önleme/Azaltma Temel Planı (2002) raporu, İstanbul Deprem Master Planı (2003), İstanbul Deprem Bölgeleri Haritası ve İstanbul Kentsel Dönüşüm Master Planı Analiz verileri (20।6) dikkate alınarak "öncelikli riskli alanlar" belirlenmiş ve "genel dönüşüm alanları" ile uygunluğu İstanbul il bütününü kapsayan harita üzerinde denetlenmiştir. Çalışmada, İstanbul yerleşik alan sınır büyüklügünün yaklaşık \%32'sine karşılık gelen alanın kentsel dönüşüm kapsamında olduğu belirlenmiştir. Araştırma sonucunda, "kentsel dönüşüm-gelişim alanları" ile "öncelikli dönüşüme" girmesi gereken alanlar arasında ciddi bir uyuşmazlık tespit edilmiştir. Bu durum İstanbul örneğinde afet risk azaltımı ve güvenli yerleşim alanları oluşturma hedefinin büyük oranda başarılamadığını göstermektedir.

Anahtar sözcükler: Afet riski; kentsel dönüşüm; İstanbul; öncelikli riskli alan; risk azaltımı; planlama.

\section{ABSTRACT}

The urban regeneration phenomenon in Turkey has emerged as a new urban policy in recent years, as is the case in many countries. In this study we examine the relationship between the "general urban regeneration areas" identified on such grounds as "disaster risk, non-compliance with zoning legislation, risky structure, risky ground structure, etc." and "priority risk areas" which have a risk factor in the real sense, in Istanbul. In the first phase of the study, quantitative data (law, year of advertisement, size, current status) related to all regeneration areas in Istanbul, announced under laws 5366, 5393 and 6306, were requested from the Ministry of Environment and Urbanization, the Istanbul Metropolitan Municipality and the district municipalities, and any incomplete information and documentation was remedied from Istanbul Urban Transformation Master Plan analysis data, a desktop study and interviews with district municipalities. In the second phase, "priority risk areas" were defined, taking into consideration the Japanese International Cooperation Agency-JICA Disaster Prevention/Mitigation Basic Plan (2002) report, the Istanbul Earthquake Master Plan (2003), the Istanbul earthquake zones map and the Istanbul Urban Transformation Master Plan Analysis (2016), and their compliance with the "general regeneration areas" was checked from a map covering Istanbul as a whole. It was found that $32 \%$ of Istanbul's built-up area border size is in the scope of the general urban regeneration areas. Furthermore, an overlay of the "urban regeneration-development areas" and the "priority risky areas" in Istanbul indicate that the goals of disaster risk reduction and the creation of safe settlements is Istanbul have largely been missed.

Keywords: Disaster risk; urban regeneration; İstanbul; priority risky areas; risk mitigation; planning.

Geliş tarihi: 07.10.2019 Kabul tarihi: 24.07.2020

Online yayımlanma tarihi: I7.12.2020

Iletişim: Yasin Bektaş

e-posta: bektasysn@gmail.com 


\section{Giriş}

Kent mekânında sürekli değişim ve dönüşüm baskısını oluşturan çeşitli nedensellikler bulunmaktadır. Bu nedenselliklerin başında nüfusun artması, kent ekonomisinin gelişmesi, kent içi erişilebilirlik, yapıların yıpranması ve çeşitli afet riskleri' gelmektedir. Kentsel mekânda dönüşümü yönlendiren bu tetikleyicilerin belli bir etkileşim içerisinde olduğu söylenebilir (Tekeli, 2003). Kenti bir dönüşüm mekânı olarak düşündüğümüzde bir diğer kavramsallaştırma ise; kentlerin gelişim aşamaları üzerinden yapılan tanımlamadır. Kentler tarihsel olarak gelişim süreçleri incelendiğinde, üç önemli dönüşüm aşaması üzerinden değerlendirirler. Bunlardan ilki sanayi devrimiyle birlikte modernite, ulus-devlet oluşumu ve kentleşme süreçlerine paralel bir dönüşümü tarif etmektedir (Türkün, 20I5). İkinci dönem, 2. Dünya Savaşı ile başlayarak, savaş sonrası yıkılan kentlerin yeniden inşası ve sosyal refah devleti politikalarının etkisiyle şekillenen bir kentleşme sürecine karşılık gelmektedir (Türkün ve Kurtuluş, 2005). Üçüncü dönem ise, kapitalizmin 1970’lerden sonra yaşadığı sermaye birikim krizine bağlı olarak, 1980 sonrası neoliberal politikalarla dünya mekânının farklı ölçeklerde sosyal, politik ve mekânsal olarak yeniden yapılanması çerçevesinde açılanmaktadır (Hirst ve Zeitlin 199I; Arbaci 2007; Fainstein 2008). 1990'larla birlikte "kentsel dönüşüm” kavramı kentlerdeki ekonomik gelişmeyi yeniden canlandırma göreviyle, büyük sermayenin kentsel arazi üzerinden birikim sağlama aracı rolünü üstlenmiştir. Bu sebeple kentsel dönüşüm politikaları, güçlü bir sermayeyi çekecek büyük ölçekli kentsel dönüşüm projeleri üzerine temellenmiştir (Weber 2002; Scott 2006; Swyngedouw vd. 2002, Taşan-Kok, 2010).

Kentlerde özellikle 2000’li yıllardan sonra üçüncü dönüşüm evresi içerisinde yeni bir ikinci kırılma noktası ortaya çıkmıştır. Yeni bir kentleşme stratejisi olarak özel sektör iş birliğiyle ekonomik yeniden canlanma görevi atfedilen kentsel dönüşüm olgusunun, son yıllarda dünyanın birçok ülkesinde olduğu gibi Türkiye'de de "yeni kent politika"sının önemli bir unsuru olarak gündeme geldiği görülmektedir. (Smith, 2002; Ataöv ve Osmay 2007; Yalçıntan vd. 20।4; Bektaş, 20l4). Türkiye'de 2000'li yıllarda sermaye birikimi ve kalkınmada en önemli gündem maddesi kentsel dönüşüm olgusudur. Bu yeni kentleşme pratikleri içerisinde kaçak yapılaşmış alanlar, gecekondu alanları, tarihi konut alanları, yıpranan konut alanları, eski liman-sanayi alanları ve boş alanlar kentsel dönüşümün müdahale alanlarıdır (Türkün ve Yapıcı, 2009; Yalçıntan vd. 20I4; Türkün, 20I5; Bektaş, 20l4). Bu dönüşüm müdahalelerinin çoğu zaman "afet riski, imar mevzuatına aykırılık vb." gibi gerekçelerle sunulduğu ve yapılan uygulamaların meşrulaştı- rıldığı görülmektedir. Kentsel dönüşüm aynı zamanda ekonomiyi canlandırdığı, işsizliği azalttığı gibi gerekçelerle de meşrulaştırılmaktadır (TOKI, 20II). Kentsel dönüşüm projelerinin çoğu zaman ekonomik önceliklerle ve sermaye yatırımlarıyla yönlendirilmesi sonucunda; “plan kararlarının bütünlüğünü bozması, ekolojik dengeyi ve öncelikli riskli alanları göz ardı etmesi” gibi önemli problemler ortaya çıkmıştır (Yalçıntan vd. 20I4; Türkün, 20I5; Terzi, 20I8; Bektaş, 20I4). Böyle bir dönüşüm müdahalesi, doğal kaynakları tehdit etmekte ve afet risklerinin azaltılmasında etkin bir araç olarak kullanılamamaktadır. Kentin farklı noktalarında ortaya çıkan, birbirinden ayrı gibi görünen tüm dönüşüm alanları, aslında kentsel ölçekte genel bir dönüşüm sorununun farklı görüntülerini oluşturmaktadır (Tekeli, 2003). Hem yasal anlamda hem de dönüşüm projeleri kapsamında dağınık bir halde bulunan ve çeşitli gerekçelerle başlatılan genel kentsel dönüşüm alanları ${ }^{2}$ ile gerçek durumdaki riskli alanlar arasındaki uyumsuzluğun araştırılması bu çalışmanın araştırma sorusudur.

Yeni dönemdeki kentsel dönüşüm olgusunu diğer dönemlerden ayıran en önemli özellik; organize olmuş bir dönüşüm sistemiyle, bir grup güçlü aktörle (kamu-özel) çok hızlı bir şekilde gerçekleşiyor olmasıdır (Tekeli, 20I3; Güzey, 20I5). Böyle bir dönüşüm sürecinde kentsel dönüşümle ilgili çıkarılan yasal düzenlemelerin kentler üzerinde önemli bir etkisi bulunmaktadır. Yasal düzenlemelerle dönüşümde aciliyet söylemi gündeme gelmiş ve büyük ölçekli kentsel dönüşüm projeleriyle bu soruna çözüm getirileceği öne sürülmüştür (Bartu Candan ve Kolluoğlu, 2008; Bektaş, 20I4).

2000'li yıllardan başlayarak günümüze kadar geçen süreçte dönüşümü teşvik edecek birçok yasal düzenlemeler yapılmıştır. Bu dönemde kentsel dönüşüm olgusunun niteliği, ölçeği, hızı ve müdahale alanları değişime uğramıştır. Kentsel dönüşüm ilk uygulanmaya başladığı dönemde planlamaya alternatif bir müdahale biçimi olarak değerlendirilse de (Şahin, 2006), artık günümüzde planlama üzerinde ciddi bir güce ulaşmıştır (Bektaş, 20I4).

Son yıllarda kentsel dönüşüm olgusu üzerine farklı boyutlarıyla ele alan çok sayıda araştırma yapılmıştır. Ancak bu araştırmalarda tüm kentsel dönüşüm alanları ile öncelikli riskli alanlar arasındaki uygunluğu karşılaştıran bir çalışma yapılmamıştır. Araştırmanın hipotezi; dönüşüm kanunlarında ortak olarak belirtilen "deprem riski, zemin riski, yapı riski, güvenlik" vb. gerekçelerle ilan edilen "genel kentsel dönüşüm alanlarının”, gerçek risk faktörü taşıyan "öncelikli riskli alanlara” göre oluşturulmadığıdır. Bu hipotezden hareketle araştırmanın amacı, 2000'ler sonrasında ortaya çıkan kentsel

\footnotetext{
Deprem riski, sel riski, yangın riski, fırtına, heyelan riski, tsunami vb.

2 Araştırmada yenileme alanı, dönüşüm alanı, riskli alan, rezerv alan vb. alanların tamamı genel kentsel dönüşüm kavramıyla açıklanmaktadır. Genel kentsel dönüşüm alanları ile 2000 sonrası dönemde çıkarılan; 5366 sayılı “Yıpranan Tarihi ve Kültürel Taşınmaz Varlıkların Yenilenerek Korunması ve Yaşatılarak Kullanılması Hakkında Kanun”, 5393 sayılı “Belediye Kanunu”, 5998 sayılı” Belediye Kanunu’nda Değişiklik Yapılmasına İlişkin Kanun” ve 6306 sayılı "Afet Riski Altındaki Alanların Dönüştürülmesi Hakkında Kanun" kapsamında ilan edilen tüm kentsel dönüşüm projeleri kastedilmektedir.
} 
dönüşüm olgusunu ayrı ayrı açıklayan ve bağımsız kabul etme yaklaşımı yerine; kentsel dönüşüm yasaları çerçevesinde ilan edilen "genel kentsel dönüşüm alanları" ile "öncelikli riskli alanlar" arasındaki ilişkinin İstanbul'da yapılan araştırma sonuçlarına dayanarak sorgulanmasıdır. İstanbul günümüzde ülke nüfusun en fazla oranda yaşadığı bir alanken, aynı zamanda küresel sermayeyi kendine çekecek en büyük kentsel dönüşüm projelerine sahiptir. Büyük projelerle birlikte kentin yerleşik alan sınırı kuzeye doğru yayılmaktadır. İstanbul yerleşik alan sınırının yüzde kaçının kentsel dönüşüm altında olduğu sorusunun cevabı ve bu dönüşüm alanlarının niteliği, ortaya konan gerekçelerle, gerçek risk faktörü taşıyan durumun resmini netleştirmektedir.

Araştırmanın teorik çerçevesinde ilk olarak, neoliberal kentsel dönüşüm politikaları tartışmaya açılmaktadır. Daha sonra Türkiye'deki kentsel dönüşüm olgusu ve yasal düzenlemeler kronolojik olarak yansıtılmakta ve özellikle 2000'ler sonrasında yeni dönem kentsel dönüşüm politikaları olgusal olarak açıklanmaktadır. ${ }^{3}$ Alan araştırması sonuçlarının aktarıldığı bölümde ise genel kentsel dönüşüm uygulamaları ile öncelikli riskli alanlar arasındaki ilişki İstanbul kenti örneğinde alan araştırması ile sorgulanmaktadır.

\section{Bilgi Toplama Yöntemi}

Çalışmada nicel araştırma yöntemi kullanılmıştır. İlk etapta, İstanbul'daki tüm kentsel dönüşüm alanlarıyla ilgili niceliksel veriler toplanmış, daha sonra bu niceliksel veriler üzerinden tablo ve harita oluşturularak niteliksel çıkarımlar yapılmıştır. İlk etapta; genel kentsel dönüşüm alanları (dönüşüm alanı, yenileme alanı, riskli alan, rezerv yapı alanı) hakkında bilgi ve belge almak için bilgi edinme kanunu kapsamında, İstanbul Büyükşehir Belediyesi, tüm ilçe belediyeleri, Çevre ve Şehircilik Bakanlığı ile 5366 sayılı "Yıpranan Tarihi ve Kültürel Taşınmaz Varlıkların Yenilenerek Korunması ve Yaşatılarak Kullanılması Hakkında Kanun”, 5393 sayılı "Belediye Kanunu”, 5998 sayılı” Belediye Kanunu'nda Değişiklik Yapılmasına İlişkin Kanun” ve 6306 sayılı "Afet Riski Altındaki Alanların Dönüştürülmesi Hakkında Kanun" kapsamında ilan edilen (2019 yılına kadar) 99 adet projenin; yasa adı, proje ilan yılı, alan büyüklüğü (hektar) ve mevcut durum bilgileri elde edilmiştir. Geri dönüş yapmayan veya eksik bilgi ve belge gönderen kurumların bilgileri İstanbul Kentsel Dönüşüm Master Planı analiz verileri, internet üzerinden yapılan araştırmalar ve ilçe belediyeleriyle yapılan görüşmeler sonucunda tamamlanmıştır. "Genel kentsel dönüşüm” alanlarıyla ilgili toplanan tüm niceliksel veriler çalışmada bütünleştirilmiş tablo haline getirilmiştir. Ayrıca bu tablodan bazı veriler gruplaştırılarak yeni tablolar üretilmiş ve çalışma amacına yönelik olarak metin içerisinde yorumlanmıştır.
İkinci etapta; İstanbul il bütününde "öncelikli riskli alanlar" Japon Uluslararası İşbirliği Ajansı-JICA Afet Önleme/Azaltma Temel Planı (JICA ve IBB, 2002) raporu, İstanbul Deprem Master Planı (2003), İstanbul Deprem Bölgeleri Haritası, İstanbul Kentsel Dönüşüm Master Planı Analiz verileri (20l6) dikkate alınarak; I. derece deprem bölgeleri, yüksek hassaslı sıvılaşma riski alanlar, ağır hasarlı bina alanları üst üste çakıştırılarak "öncelikli riskli alanlar" belirlenmiş; ve bu riskli alanlar ile mevcut genel dönüşüm alanları aynı harita üzerinde karşılaştırılarak yorumlanmıştır. Böylelikle "genel kentsel dönüşüm alanları" ile "öncelikli riskli alanlar" arasındaki uyum ve uyumsuzlukların tespit edilmesi mümkün hale gelmiştir.

\section{Neoliberal Kentleşme Politikaları Çerçevesinde Kentsel Dönüşüm Olgusu}

1980'ler sonrasında yaygınlaşan neoliberal ekonomi politikaları uluslararası, ulusal ve bölgesel ölçeklerde sosyal, politik ve mekânsal yeniden yapılanmaları ve dönüşümleri harekete geçirmiştir. Bu süreçte özellikle büyük kentlerde piyasa aracılığıyla, kentsel toprak rantı en önemli sermaye birikim araçlarından biri olmaktadır (Arbaci 2007, Fainstein 2008, Swyngedouw vd. 2002, Hirst ve Zeitlin 1991). Gelişen altyapı olanakları, vergi avantajı, işgücü ilişkileri neticesinde kolaylaşan sermaye yatırımı ve küresel ekonomi içerisinde şehirlerin artan yarışmacı güçleri, kentsel dönüşümü tetikleyen en önemli unsurlardır. Bu süreçte kentlere küresel sermayeyi çekecek büyük ölçekli kentsel dönüşüm projeleri pazarlayarak ekonomik gerilemeyi hafifletme görevi atfedilmektedir (Taşan-Kok, 2010, Harvey 1989, Roberts 2005, Andersson vd. 2010, Swyngedouw vd. 2002, Weber 2002, Turok 2004, Loftman ve Nevin 1995).

Literatürde çoğunlukla küreselleşme ve küresel kent araştırmalarıyla değerlendirilen neoliberal kentleşme ve kentsel dönüşüm, kentlerde finans sektörü ile hizmetler sektörünün büyümesine neden olmaktadır (Harvey 1989, Weber 2002, Scott 2006, Öktem 2006, Duman ve Coşkun 20I5). Bu alanlarda yapılan yatırımların, küresel ölçekte sermayeyi ve nitelikli işgücünü çekerek, kentlerin ekonomik rekabet gücünü arttıracağı beklenmektedir. Özellikle büyük kentlerin rekabet edebilirliğini güçlendirecek yeni kentsel politika aracı, uluslararası sermayeyi çekecek mega-öncü gelişim/dönüşüm projeleridir. Bu projelerde toplumsal gelişim yerine mekânsal gelişim hedeflenmektedir. Kamu-özel ortaklıklarıyla gerçekleştirilen öncü projelerin, kentsel imajları parlatmak suretiyle arazi değerlerini arttırarak, yerelde ekonomik aktiviteleri sağlayacağı varsayılmaktadır. Kentsel dönüşüm kentlerde, ofis kuleleri, alışveriş merkezleri, stadyumlar, marinalar, lüks kapalı konut siteleri, karma kullanımlı yerleşimler gibi bir dizi mekânsal gelişimi de beraberinde getirmiştir (Fainstein 2008, Montgomery 2003, Peck 2005, Amin ve Thrift 2007, Pratt 2008, Scott 2006, Tallon 2010, Özdemir 2010, Erman 2016).

\footnotetext{
3 Her bir dönüşüm evresinin kendi içerisinde çok kapsamlı ve çok boyutlu ilişkileri barındırması nedeniyle, çalışmada 2000 öncesi dönüşüm evrelerinde öne çıkan özellikler kronolojik olarak sıralanmakta, özellikle 2000 sonrası dönemde ortaya çıkan yeni dönem kentsel dönüşüm olgusu irdelenmektedir.
} 
Çok sayıda araştırma, kentlerde artan bu ekonomik aktivitelerin yoksulluğu ve ayrışmayı azaltmadığını; aksine kentsel eşitsizlikleri, zengin adacıklarını, sosyal güvencesiz yaşam koşullarını ve yoksulluğu arttırdığını göstermektedir (Harvey 1989, Roberts 2005, Swyngedouw vd. 2002, Scott 2006, Turok 2004, Eraydın 2008, Işık ve Pınarcıoğlu 2009, Öktem Ünsal ve Türkün 20|4). Günümüzde bu süreç neredeyse tüm mega şehirlerde benzer sonuçlar doğurmaktadır. Büyük kentsel dönüşüm projeleri öncelikle piyasanın kârlılı̆ına ve rekabet edebilirliğine yönelmektedir (Fainstein 2005, Fainstein 2008, Loftman ve Nevin 1995). Bu yönelim gelecekte oluşacak spekülatif kentsel toprak rantına dayalı olduğu için çoğunlukla büyük riskler taşımıştır (Swyngedouw vd. 2002, Loftman ve Nevin, 1995). Dolayısıyla bu tür öncü gelişim/dönüşüm projeleri kısa dönemde avantajlar sağlıyor gibi görünse de uzun vadede finansal risk ve birçok sosyo-mekânsal eşitsizliklerle birlikte daha büyük sorunları ortaya çıkarmaktadır (Loftman ve Nevin, 1995). Özellikle yoksulluğun yoğunlaştığı kent merkezlerinde, emlak değerlerinin düşmesiyle birlikte başlatılan dönüşüm çalışmaları ve yeni orta sınıfının talepleri, emlak değerlerini artırmakta ve dezavantajlı yoksul grupların yerinden edilmesiyle sonuçlanabilmektedir (Slater 2006, Türkün ve Ulusoy 2002, Smith 2002, Şen 2005, Uzun 2006, İslam ve Enlil 2010).

Özetlemek gerekirse; neoliberal kentleşme politikaları kentlerde, sosyal, ekonomik, mekânsal ve yönetimsel boyutta birçok dönüşümün tetikleyicisi olmuştur. Bu kentleşme politikalarının en önemli uygulama aracı, uluslararası para akışını çekebilmek amacıyla oluşturulan öncü kentsel gelişim/dönüşüm projeleridir. Bu durum özellikle özel sektör yatırımcısına büyük avantajlar sağlarken, dezavantajlı kesimler açısından yoksulluk, mekânsal ayrışma, kentsel eşitsizlik gibi ciddi problemlere zemin hazırlamıştır.

\section{Türkiye'de Kentsel Dönüşüm Olgusu ve Yasal Düzenlemeler}

Türkiye'de kentsel dönüşüm olgusuna tarihsel bir süreç içerisinde bakıldığında farklı dönemlerde farklı dönüşüm değişkenleri ve uygulamaları karşımıza çıkmaktadır. Her bir dönem kendi içerisinde farklı yapısal bağlamları barındırmakta, farklı sosyo-ekonomik, fiziksel ve yönetimsel koşulları içermektedir (Ataöv ve Osmay, 2007). Dolayısıyla tüm bu süreçlerin etkileşimi sonucunda, kentlerde farklı dönüşüm uygulamaları ortaya çıkmıştır. Türkiye'de tarihsel süreç içerisinde kentsel dönüşüm, genel kentleşme süreçlerinin başladığı 1950'li yıllardan başlayarak günümüze kadar üç önemli dönemde farklılaşmaktadır. Bunlardan ilki Türkiye'nin büyük metropol şehirlerinde sanayileşme ve hızlı kentleşme süreçlerinin yaşandığı 1950-1980 arası dönemdir. 1950'ler sonrası benimsenen liberal ekonomi politikaları ve 1960 'larda ithal ikameci sanayileşme modelinin yaygınlaşmasıyla birlikte, özellikle büyük kentler çok hızlı bir kentleşme sürecini yaşamıştır. Bu dö- nemde gözlenen en önemli dönüşüm yansıması gecekondulaşmadır. Bu yıllarda gecekondular büyüyüp mahalle ölçeğine ulaşmıştır (Şenyapılı 1998, Şenyapılı 2004; Sey, 1998a; Tekeli, 1998). Bu dönemde Gecekondu alanlarıyla ilgili en önemli kanunlardan birisi 1966 yılında çıkarılan 775 sayılı Gecekondu Yasası'dır. Yasa kapsamında gecekondu alanlarında üç tür yeni düzenleme getirilmiştir. Bunlar gecekondu ıslah, tasfiye ve önleme bölgeleridir. Bu müdahale türünde tamamen yıkıma gidilmemektedir. Gecekondu alanlarında altyapının geliştirilmesine olanak verilmiştir (Gecekondu Kanunu, Madde I3, 22). Bir diğer önemli dönem ise, neoliberal ekonomi politikalarının ve küreselleşmenin etkilediği 1980-2000 yılları arasıdır. İhracata dayalı neoliberal ekonomi politikaları kentsel nüfus artışında ikinci bir kırılmaya sebep olmuştur. $\mathrm{Bu}$ dönemde ruhsatlı ve ruhsatsı yapılaşma ile kentsel yayılma gözlenmiştir (Ataöv ve Osmay, 2007; Türkün, 20l4b). Plansız gelişen alanlarla ilgili bir dizi imar afları çıkarılmış ve bu aflarla birlikte gecekondu alanları yasallaşmıştır. Bu yasalardan her biri bir diğer yasanın yetki alanını giderek genişletmiştir (Şenyapılı, 1998). Islah imar planlarıla zamanla dört katlı apartman bloklarına dönüşen gecekondu alanları, konut sektöründe alınıp satılan ticari bir metaya dönüştürülmüştür (Ataöv ve Osmay, 2007; Türkün vd. 2014a). Islah imar planları sonucunda yıkılıp yeniden inşa edilen gecekondu alanları kentlerde ciddi bir yoğunluk artışı meydana getirmiştir (Altaban, 1998). Ayrıca fiziksel olarak yıpranmış ve yaşam kalitesi düşmüş alanlarda kentsel yenileme uygulamaları yapılmıştır. Aynı zamanda toplu konut kanunuyla birlikte konut ihtiyacının giderilmesinin yanı sıra (Sey, 1998b); gecekondu alanlarının dönüştürülmesi ve tarihi alanların iyileştirilmesi de hedeflenmiştir (Ataöv ve Osmay, 2007). 1980 sonrası uygulana politikalar sonucunda altyapısı yetersiz, yüksek yoğunluklu ve niteliksiz konut alanları ortaya çıkmıştır (Türkün vd., 20l4b).

2000 sonrası dönemde ise; Avrupa Birliği uyum müzakereleri, uluslararası ortaklıklar kapsamındaki uygulamalar ve özelleştirme politikaları dönemin ayırt edici yapısal özellikleridir. Piyasa aracılığıla ekonomik yeniden canlanma görevi atfedilen kentsel dönüşüm olgusu yeni bir kentleşme stratejisi olarak gündeme gelmiştir (Ataöv ve Osmay, 2007; Bektaş, 2014). Bu sebeple inşaat sektörünün ve büyük sermaye gruplarının daha fazla yatırım yapacağı yeni kentsel politikalar benimsenmiştir (Türkün vd., 20l4b). 2000'li yıllar aynı zamanda inşaat şirketlerinin uluslararası pazarda yerini aldığı, inşaat sanayinin ve teknolojilerinin de gelişti dönemdir (Ataöv ve Osmay, s.7I). Kentsel dönüşümün "deprem, yasadışılık, göç, plansız kentleşme, yoğun nüfus, suç örgütleri, risklilik..." gibi sorunlara karşı çözüm olarak sunulduğu ve yapılan uygulamaların yasal dayanağının oluşturulduğu gözlenmektedir (Bartu Candan ve Kolluoğlu 2008; Bektaş, 20I4).

Yeni dönem kentsel dönüşüm yasaları gayrimenkul sektörünün sermaye birikimine kolaylık sağlayacak şekilde oluştu- 
rulmuştur. Yapılan yatırımların büyük bir bölümü uluslararası sermayeden oluşmaktadır. Türkiye'de doğrudan yabancı yatırımlar 1952 yılında 2,2 milyon dolarken, 2007 yılında 22,5 milyar dolara çıkmıştır. İnşaat sektörüne yapılan yabancı yatırımlar 2000 yılında 22 milyon dolarken, 2007 yılında 735 milyon dolara yükselmiştir (Yalçıntan vd., 2014, s.5I). Aynı zamanda 2012 yılında ise, 2,6 milyar dolar, 2014 yılında 4,3 milyar dolar, 2017 yılında ise 4,6 milyar dolar gayrimenkul yatırımı yapılmıştır (Sezgin, 2018). Bu oran Ocak - Ekim 2018 döneminde 4,I milyar dolara gerilemiştir (KPMG, 2019). Bu veriler Türkiye ekonomisinin sadece ulusal sermayeye dayanmadığını ve küresel ekonomi çerçevesinde artan sermaye birikiminin, kent topraklarında gayrimenkul yatırımlarına yöneldiğini göstermektedir $^{4}$ (Yalçıntan vd., 20I4, s.5I). Bu veriler TÜiK İşgücü istatistiklerine de yansımaktadır. 2018 Ekim döneminde yan sektörler dahil olmamakla birlikte, istihdam edilenlerin \%6,7'si inşaat sektöründe yer almıştır. Bu oranın son birkaç yıldır \%7 civarında seyrettiği gözlenmektedir.

1999 Marmara Depremi ve 200I ekonomik krizi yeni dönem kentsel dönüşüm politikalarını tetikleyen bir diğer önemli faktörlerdir. Yatırımların öncelikle kentsel topraklara kaymasıyla, gayrimenkul ve inşaat sektörünün ekonomik büyüme içerisindeki önemi giderek artmıştır. Yasal ve kurumsal düzenlemeler yeni dönem kentsel dönüşüm uygulamalarını ve yatırımları hızlandıran en önemli araçlardan biridir. Çevre ve Şehircilik Bakanlığı, TOKI (Toplu Konut İdaresi Başkanlı̆̆ı) ve GYO (Gayrimenkul Yatırım Ortaklığı)'ların yapısındaki değişimlerle bu kurumlar yeni kentsel dönüşüm uygulamalarında önemli bir etkiye sahip olmuştur. TOKi 2003-2010 yılları arasındaki dönemde büyük inşaat şirketleriyle ("hasılat paylaşımı” ve "kat karşılı̆̆” gibi yöntemlerle) konut üretimine katılmıştır. Ayrıca inşaat sektöründe GYO'lar da kurumlar vergisinden muaf olması, gelir vergisinden muaf olması gibi avantajlarla ${ }^{5}$ önemli aktörler olarak öne çıkmıştır (Ankara Enstitü Vakfı, 2012 akt. Türkün vd. 20I4b).

Kentsel dönüşümde en önemli aktör olan TOKI, 2004 yılında başlayan yasal değişikliklerle ciddi yetkilere kavuşmuştur. TOKI yeni yasal düzenlemelerle yapılandırılarak neoliberalleştirilmiştir (Erman, 2016). 2004 tarihinde 5I62 sayılı Yasayla Toplu Konut Kanunu'nda değişiklik yapılarak, TOKi Başkanlığı gecekondu dönüşüm projesi uygulayacağı alanlarda her tür ve ölçekteki imar planlarını yapmaya ve yaptırmaya yetkili kılınmıştır. 2007 tarihinde 5609 sayılı (775 sayılı) Gecekondu
Kanunu'nda değişiklik yapılarak, TOKi belediye sınırları içinde gecekondu islah, gecekondu tasfiye ve gecekondu önleme bölgelerinin sınır onayını yapmaya yetki kazanmıştır. Yasa aynı zamanda TOKI denetiminde imar ve ıslah planlarının belediyelerce hazırlanması ve TOKI'ye, plan tekliflerini red veya onaylamaya yetkili kılınması gibi ayrıcalıklar verilmiştir (TMMOB, 2008). TOKI'nin son 14 yıl içinde 60 ilde yaklaşık 190 kentsel dönüşüm projesi yürüterek, bu kapsamda toplam I40 bin konut üretimi yapılmıştır. TOKI'nin ürettiği toplam konut sayısı içinde, kentsel dönüşüm konutlarının oranı \%35'e yükselmiştir (www.toki.gov.tr/haber, 20l8).

Birbiri ardına çıkarılan kentsel dönüşüm yasalarıyla, bazı kamu kurumların yetkileri sürekli arttırılmış, dönüşüm ve inşaat sektörü önündeki engeller kaldırılmıştır. Genel kentsel dönüşüm alanlarının yasal dayanakları ${ }^{6}$ incelendiğinde; yetkini merkezileştirilmesi, plan kararlarının zedelenmesi ve planlama yetkilerinin giderek parçalanması gibi sorunlar bu yasaların ortak özelliği haline gelmiştir. 2012 yılı öncesinde, çeşitli gerekçelerle ve boş alanlarda dönüşüm uygulamalarını olanaklı hale getiren 5393 sayılı 'Belediye Kanunu'nun 73. maddesi ve kentsel sit alanlarında yenileme uygulamalarını yapılabildiği 5366 sayılı 'Yıpranan Tarihi ve Kültürel Taşınmaz Varlıkların Yenilenerek Korunması ve Yaşatılarak Kullanılması Hakkında Kanun'la ilerleyen kentsel dönüşüm uygulamaları; 2012 yılında 6306 sayılı 'Afet Riski Altındaki Alanların Dönüştürülmesi Hakkında Kanun'unun yürürlüğe girmesiyle yeni bir boyuta ulaşmıştır. 20II Van Depremi sonrasında gündeme gelen ve günümüzde kentsel dönüşüm-gelişim projelerinde birincil araç olan afet yasası, dönüşümde "aciliyet" ve "afet riski” söylemini yeniden gündeme getirmiştir. Dönüşüm yasaları içerisinde en kapsamlı ve merkezi yetkiyi temsil eden afet yasası, 3194 sayılı İmar Kanunu, 2960 sayılı Boğaziçi Kanunu, 683I sayıl Orman Kanunu, 4342 sayılı Mera Kanunu vd. ${ }^{7}$ gibi kentle ilgili en temel ve önemli yasaların kısıtlamalarına tabi olmayarak ciddi üstünlükler içermekteydi. Ancak yasanın içeriğini ilişkin eleştiriler; devamında Anayasa Mahkemesine yapılan başvurular neticesinde yukarıda sayılan maddeler ve bazı maddelerinde iptal veya değişikliğe gidilmiştir. Yasa kapsamında afet riski sadece deprem riski olarak görülmekte ve bir inşaat faaliyeti olarak algılanmaktadır. ${ }^{8}$ Ancak kentlerin sel, yangın, heyelan, tsunami, iklim değişikliği, kimyasal kaza ve patlamalar gibi çoklu kentsel risklere karşı kırılganlıkları bulunmaktadır. Riskli alanların belirlenmesinde detaylı bir analiz yapılmamakla birlikte; risk dışındaki faktörlerin daha baskın

\footnotetext{
4 Aynı zamanda yabancı ortak sermayeli şirket sayıları da giderek artmaktadır. 20I8'de kurulan yabancı ortak sermayeli şirket sayısı, 6.73।'den I3.405'e yükselmiştir (httt:// www.milliyet.com.tr/kurulan-yabanci-ortakli-sirket-ekonomi-28I45।5/). Bir önceki yıla kıyaslandı̆̆ında, bunun yaklaşık 2 katına çıktığı görülmektedir.

5 Bkz. Kurumlar Vergisi Kanunu 5. Madde; Gelir Vergisi Kanunu 94. Madde.

65393 sayılı Belediye Kanunu'nun 73. Maddesi, 5366 sayılı Yıpranan Tarihi ve Kültürel Taşınmaz Varlıkların Yenilenerek Korunması ve Yaşatılarak Kullanılması Hakkında Kanun, 5998 sayılı Belediye Kanunu'nda Değişiklik Yapılmasına İlişkin Kanun ve 6306 sayılı Afet Riski Altındaki Alanların Dönüştürülmesi Hakkında

73573 sayılı Zeytinciliğin Islahı ve Yabanilerinin Aşılattırılması Hakkında Kanun, 7269 sayılı Umumi Hayata Müessir Afetler Dolayısıyla Alınacak Tedbirlerle Yapılacak Yardımlara Dair Kanun, 189 sayılı Milli Savunma Bakanlı̆ı̆'nın İskan İhtiyaçlarıyla ilgili kanun, 2565 sayılı Askeri Yasak Bölgeler ve Güvenlik Bölgeleri Kanunu, 2634 sayılı Turizm Teşvik Kanunu, 362I sayılı Kültür ve Tabiat Varlıklarını Koruma Kanunu, 362I sayılı Kıyı Kanunu, 5366 sayılı Yıpranan Tarihi ve Kültürel Taşınmaz Varlıkların Yenilenerek Korunması ve Yaşatılarak Kullanılması Hakkında Kanun, 5403 sayılı Toprak Koruma ve Arazi Kullanımı Kanunu.

8 Çevre ve Şehircilik Bakanlığı açıklamalarında “...deprem değil bina öldürüyor...” ifadesi bu algıyı yansıtmaktadır.
} 
olması nedeniyle öncelikli riskli alanlar göz ardı edilebilmektedir. Tekil ve parçacıl yürütülen riskli alanlar, riskli yapı ve rezerv alanlar kent planının nüfus tahminlerine uymamakta, kentin teknik ve sosyal altyapı dengesini bozmaktadır. Afet yasasına eklenen 25. madde kapsamında bina ölçeğinde yenileme kararı verilebilmesi için gereken 2/3 çoğunluk kararı, alan bazında da uygulamasının önünü açmıştır. Bu ek maddeye göre Çevre ve Şehircilik Bakanlığı, "Kamu düzeni veya güvenliğinin olağan hayatı durduracak veya kesintiye uğratacak şekilde bozulduğu yerlerde; planlama ya da altyapı hizmetleri yetersiz olan veya imar mevzuatına aykırı yapılaşma bulunan yahut yapı ya da altyapısı hasarlı olan alanlar" ve "üzerindeki toplam yapı sayısının en az \%65’i imar mevzuatına aykırı olan veya yapı ruhsatı alınmaksızın inşa edilmiş olmakla birlikte sonradan yapı ve iskân ruhsatı alan yapılardan oluşan alanlar" için "riskli alan" kararı alarak Bakanlar Kuruluna onay için teklif götürebilmektedir. İstanbul'daki mevcut konut stokunun \%60'ının imar mevzuatına uymadığı düşünüldüğünde, ek maddenin getirdiği kolaylıkla İstanbul'un en az \%60'ının riski alan kapsamında değerlendirilebileceği anlamına gelmektedir. ${ }^{9}$

Kentsel dönüşüm uygulamalarının müdahale alanları incelendiğinde; kaçak yapılaşmış alanlar, doğal tehlikeler açısından sakıncalı alanlar, gecekondu alanları, yıpranan konut alanları, tarihi konut alanları dönüşüm kapsamındayken, aynı zamanda boş alanlar, mevcut imar planlarıyla dönüşebilecek durumdaki alanlar da kentsel dönüşüm kapsamına girmiştir (Bektaş, 20I4; Türkün, 20I5). Aşağıdaki tablodan da izlenebildiği gibi (Tablo I); 2004 yılından başlayarak yeni dönem kentsel dönüşüm yasalarında hem yetkilerin hem de müdahale alanlarının giderek genişletildiği görülmektedir. Ayrıca yetkinin giderek merkezileştirildiği; kentin üst ölçekli plan kararlarının dikkate alınmadığı ve uygulama alanlarının kent bütününde parçalandığı izlenmektedir. Her ne kadar yasalarda yerel halk katımının sağlandığı, çevreye ve ekolojik dengeye duyarlı; doğal, tarihi, kültürel dokuya uygun, afet risklerinin azaltılacağı yerleşimlerin planlanması hedeflense de şimdiye kadar yapılan çoğu uygulamada bu hedeflerin gerçekleştirilemediği görülmektedir (Terzi, 2018; Bektaş, 2014).

Özetle, 2000 sonrası dönemde kentsel dönüşüm politikaları yeni bir evreye girmiştir. Bu dönemde yaşam alanlarındaki dönüşüm uygulamaların dört farklı biçimde ortaya çıktığı görülmektedir. Bunlardan en kapsamlı ve yaygın olanı kentsel alanlarda büyük çapta kentsel yenilemedir. Bunun devamında mal sahipleri tarafında parsel bazlı dönüşüm/iyileştirme; yeni site-kapalı yerleşimlerin yeniden geliştirilmesi ve tarihi ko- nut alanlarında devam eden soylulaştırma biçimleri dönemin ayırt edici özellikleridir (Ataöv ve Osmay, s.7I). Ayrıca bu dönemde kamu kurumlarına verilen yetkiler plan kararlarının ve plan kademelenmesinin zedelenmesine yol açmıştır. Yaklaşık otuzbeş farklı kurumun plan yetkisi bulunmaktadır. $\mathrm{Bu}$ süreç, yerel yönetim planlama yetkilerinin giderek parçalanmasına neden olmuştur (Tekeli, 20I3). Yetki karmaşası kentsel ölçekte dönüşüm alanlarında da benzer sonuçları ortaya çıkarmıştır. Bu dönemde dönüşümle ilgili çıkarılan yasalar gayrimenkul sektörünün sermaye birikimine kolaylık sağlamaktadır. Hem yabancı sermaye yatırımları hem de köprüler, havalimanı, altgeçitler ve diğer önemli ulaşım projeleri gibi büyük kamu yatırımlardan en çok pay alan kent kuşkusuz İstanbul'dur. ${ }^{10}$ Aynı zamanda deprem riski" başta olmak üzere, sel, yangın, fırtına, tsunami, kaçak yapılaşma gibi çoklu kentsel risklere karşı korunmasızlığı yüksek olan kentlerden biri de kuşkusuz İstanbul'dur. Yeni dönem kentsel dönüşüm politikaları ilk ve büyük izlerini İstanbul'da göstermiştir. Bir sonraki bölümde yeni dönem kentsel dönüşüm politikaları, genel kentsel dönüşüm alanları ile öncelikli riskli alanlar uyumsuzluğu problemi ekseninde İstanbul örneği üzerinden incelenmektedir.

\section{Yeni Dönem Kentsel Dönüşüm Politikalarının İstanbul'daki Görüntüleri}

Türkiye'de yeni dönem kentsel dönüşüm projeleri afet riski, imar mevzuatına aykırılık, zemin yapısı, ekonomik büyüme gibi nedenlerle meşrulaştırılsa da yapılan uygulamaların inşaat yenileme faaliyetinin ötesine geçemediği görülmüştür. Nitekim İstanbul'da yapılan alan çalışmasında ortaya çıkan sonuçlar da bunu desteklemektedir.

İstanbul kenti toplam II5.0I8 hektar yerleşik alan sınır büyüklügüunün yaklaşı \%32'sine (36.5II ha) karşılık gelen alan kentsel dönüşüm alanı kapsamındadır (Bkz. Ek- Bütünleştirilmiş Tablo). Bu dönüşüm alanlarının \%97, I9'u (35.485,38 ha) 6306 sayılı Afet Yasası kapsamındadır (Bkz. Tablo 2). Bu durum afet yasasının diğer yasalara oranla ulaştığı gücü ve etki alanını kanıtlaması açısından dikkat çekicidir. Benzer durum yasalar kapsamında ilan edilen dönüşüm alanları sayısına da yansımaktadır. 6306 sayılı Yasa kapsamında ilan edilen dönüşüm alanları sayısı oranı \%74,7 iken; bu oran 5366 sayılı Yasada \% I7,2'ye, 5393 sayılı Yasada ise \%8,l'e düşmektedir (Tablo 3). 2012 yılında afet yasasının çıkmasıyla birlikte, ilan edilen dönüşüm alanları sayısında bu yıldan itibaren ciddi bir artış yaşanmıştır (bir önceki yıla oranla 5 katlık artış, Bkz. Tablo 4).

9 http://www.mimarlikdergisi.com/index.cfm?sayfa=mimarlik\&DergiSayi=407\&RecID=4095.

10 2002-20।8 yılları arasında yaklaşık 72 milyar TL ile en çok yatırım yapılan il İstanbul'dur. Bu oranı 42 milyar TL ile Ankara, 17 milyar TL ile İzmir izlemiştir (http://www. sbb.gov.tr/yatirimlarin-illere-gore-dagilimi/).

11 İstanbul'da \%62 (+- 15\%) olasılıkla gelecek otuz yıl içerisinde 7'den büyük bir şiddette bir deprem olacağı beklenmektedir (İstanbul Kentsel Dönüşüm Master Planı Analiz verileri, 20I6). Ancak bu tahmin üzerinden yaklaşık yirmi yıl geçmiştir. Gelecek on yıl içerisinde büyük depremin olma olasılı̆ı yüksektir. 24 Eylül 2019 ve 26 Eylül 2019 (ik adet) tarihinde sırasıyla 4,6 ve 5,7-4,2 büyüklüğünde peşpeşe gelen Silivri deprem haberleri ve bunların arasında gerçekleşen artçılar beklenen büyük İstanbul depremin yeniden gündeme getirmiştir ve deprem uzmanları tarafından gerekli tedbirlerin alınmasına yönelik açılamalarda bulunulmuştur (http://www.hurriyet.com.tr/gundem/ son-dakika-ituden-son-dakika-istanbul-depremi-aciklamasi-4I338687). 
Tablo I. Türkiye'deki yeni dönem kentsel dönüşüm uygulamalarıyla ilgili yasal düzenlemeler ve genel problemler

\begin{tabular}{|c|c|c|c|c|}
\hline Yıl & Yasal düzenleme & Yetki & Müdahale alanları & Genel problemler \\
\hline 2004 & $\begin{array}{l}5162 \text { sayılı Toplu Konut } \\
\text { Kanunu'nda değişiklik }\end{array}$ & TOKi & Gecekondu & $\begin{array}{l}\text { TOKi Başkanlığı gecekondu dönüşüm } \\
\text { projesi uygulanacak alanlarda yerel } \\
\text { yönetimler üzerinde artan ayrıcalıklı } \\
\text { yetkileri }\end{array}$ \\
\hline 2005 & $\begin{array}{l}5366 \text { sayılı Yıpranan Tarihi ve } \\
\text { Kültürel Taşınmaz Varlıkların } \\
\text { Yenilenerek Korunması } \\
\text { ve Yaşatılarak Kullanılması } \\
\text { Hakkında Kanun }\end{array}$ & $\begin{array}{l}\text { Büyükşehir belediyeleri, il } \\
\text { ve ilçe belediyeleri, il özel } \\
\text { idareleri }\end{array}$ & Tarihi konut alanları & $\begin{array}{l}\text { Sit türü ifade edilmemekte; koruma } \\
\text { ve yenileme gibi zıt kavramlar } \\
\text { kullanılmakta; yerel halk ve toplumsal } \\
\text { ilişkiler dikkate alınmamakta }\end{array}$ \\
\hline 2005 & $\begin{array}{l}5393 \text { sayılı Belediye } \\
\text { Kanunu'nun 73. Maddesi }\end{array}$ & $\begin{array}{l}\text { Büyükşehir belediyeleri, } \\
\text { il ve ilçe belediyeleri }\end{array}$ & $\begin{array}{l}\text { Yıpranan konut } \\
\text { alanları, kaçak } \\
\text { yapılaşmış alanlar, } \\
\text { gecekondu alanları }\end{array}$ & $\begin{array}{l}\text { Dönüşüm tanımı yok ve hangi ölçütlere } \\
\text { göre dönüşümm yapılacağı belirsiz }\end{array}$ \\
\hline 2010 & $\begin{array}{l}5998 \text { sayılı Belediye } \\
\text { Kanunu’nda Değişiklik } \\
\text { Yapılmasına İlişkin Kanun }\end{array}$ & $\begin{array}{l}\text { Büyükşehir belediyeleri } \\
\text { (büyükşehir belediye ve } \\
\text { mücavir alan sınırı içinde); } \\
\text { İl ve ilçe belediyeleri. Eğer } \\
\text { kamu mülkiyetinde ise } \\
\text { Cumhurbaşkanlığı }\end{array}$ & $\begin{array}{l}\text { İmarlı veya imarsız; } \\
\text { yapı olan veya boş } \\
\text { alanlar }\end{array}$ & $\begin{array}{l}\text { Kentin üst ölçekli plan kararlarını } \\
\text { zedelemekte; boş alanların dönüşüm } \\
\text { kapsamına alınabilmekte }\end{array}$ \\
\hline 2012 & $\begin{array}{l}6306 \text { sayılı Afet Riski } \\
\text { Altındaki Alanların } \\
\text { Dönüştürülmesi Hakkındaki } \\
\text { Kanun }\end{array}$ & $\begin{array}{l}\text { Riskli alan (Cumhurbaşkanlığı } \\
\text { kararıyla), rezerv alan } \\
\text { (bakanlıkça) ve riskli yapı } \\
\text { (bakanlıkça) }\end{array}$ & $\begin{array}{l}\text { Alansal bazda } \\
\text { zemin yapısı } \\
\text { ve üzerinden } \\
\text { yapılaşma nedeniyle } \\
\text { risklilik oluşturan } \\
\text { tüm alanlar }\end{array}$ & $\begin{array}{l}\text { Kentin üst ölçekli plan kararlarını } \\
\text { zedelemekte; risklilik kavramı belirsiz; } \\
\text { parsel bazlı dönüşüm mümkün; diğer } \\
\text { kentsel riskler açıklanmamış, bakanlık } \\
\text { planlarda standart belirlemeye yetkili } \\
\text { ancak bu standartların ne olduğuna } \\
\text { dair açıklama yok; } 2 / 3 \text { çoğunluk ile } \\
\text { anlaşma sağlanamadığı takdirde acele } \\
\text { kamulaştırma yetkisi }\end{array}$ \\
\hline
\end{tabular}

Rezerv yapı alanları ilçelere göre değerlendirildiğinde; Yenişehir rezerv alanı'2 sınırları içerisinde kalan Arnavutköy, Başakşehir ve Küçükçekmece ilçeleri İstanbul'da hatta Türkiye'de ilan edilen en büyük rezerv yapı alanıdır. Bu alanın Kanal İstanbul projesi ve Yeni İstanbul Havalimanı gibi yeni projeler aksında önerildiği görülmektedir. Rezerv yapı alanı tanımı incelendiğinde; afet risklerinden arındırılmış, üzerinde yapılaşma olmayan yeni bir yerleşim alanı olarak algılanmaktadır. Ancak haritadan da izlenebildiği gibi (Şekil I), rezerv yapı alanın büyük bir kısmı JICA Afet Önleme/Azaltma Temel Planı (JICA ve IBB, 2002) raporuna göre yüksek hassaslı sıvılaşma riski bulunan bir bölgededir. Ayrıca bazı kısımlarından yerleşik alanlar bulunmaktadır. Risk azaltımı (risk mitigation) afet yasasının en temel hedeflerinden biri olmasına rağmen, zemin açısından problemli bir bölgede yeni yapılaşmayla afet risklerinin nasıl azaltılacağı belirsizdir. Ayrıca rezerv yapı alanı bulunan bölge tamamen yapılaşmamış bir alan değildir. Kentsel dönüşüm ve riskli alan büyüklükleri ilçelere göre değerlendirildiğinde ise; Zeytinburnu ilçesi \% I6'lık oranla (354,27 ha) ilk sırada, Fatih ilçesi \% I4'lük oranla (3।7,2 ha) ikinci sırada, Gaziosmanpaşa ilçesi ise \% I I,7’lük (262, I6 ha) oranla üçüncü sıradadır. Bunu \% I0,4'lük oranla Esenler (233,68 ha) ve \%9,7'lik oranla Tuzla ilçeleri (2।8,15 ha) takip etmektedir (Bkz. Tablo 5). Kentsel dönüşüm ve riskli alan büyüklüklerinin ilçe yerleşik alan büyüklüğüne oranlandığında ise; Zeytinburnu ilçesi \%3।,25'lik oranla birinci sırada, Gaziosmanpaşa ilçesi \%22,46'lık oranla ikinci sırada, Fatih ilçesi ise \%\% 19,97'lik oranla üçüncü sıradadır. Bu oranı \%।8,28 oranıyla Esenler ilçesi takip etmektedir (Bkz. Tablo 6). İstanbul il bütününde riskli alan

\footnotetext{
12 İstanbul Yenişehir Rezerv Yapı Alanı Çevre ve Şehircilik Bakanlığınca 15.1 I.2012 tarihinde belirlenmiş, I6.01.2019 tarihinde ise sınırları yeniden revize edilmiştir.
} 
Tablo 2. Yasa numarası ile kentsel dönüşüm alan büyüklükleri ilişkisi

\begin{tabular}{lcc}
\hline Yasa no & İlan büyüklük (ha) & Yüzde \\
\hline 5366 & 770.57 & 2,11 \\
5393 & 255.05 & 0,70 \\
6306 & $35.485,38$ & 97,19 \\
Toplam & $36.511,00$ & 100 \\
\hline
\end{tabular}

Tablo 3. Yasa numarası ile ilan edilen kentsel dönüşüm sayıları

\begin{tabular}{lcc}
\hline Yasa no & Illan büyüklük (ha) & Yüzde \\
\hline 5366 & 17 & 17,2 \\
5393 & 8 & 8,1 \\
6306 & 74 & 74,7 \\
Toplam & 99 & 100 \\
\hline
\end{tabular}

Tablo 4. İlan yılı kentsel dönüşüm ilan sayıları ilişkisi*

\begin{tabular}{lcc}
\hline İlan yılı & Sayı & Yüzde \\
\hline 2005 & 3 & 4,5 \\
2006 & 2 & 3,0 \\
2006 & 1 & 1,5 \\
2008 & 3 & 4,5 \\
2009 & 1 & 1,5 \\
2011 & 2 & 3,0 \\
2012 & 10 & 15,2 \\
2013 & 23 & 34,8 \\
2015 & 1 & 1,5 \\
2016 & 3 & 4,5 \\
2017 & 9 & 13,6 \\
2018 & 7 & 10,6 \\
2019 & 1 & 1,5 \\
Toplam & 66 & 100 \\
\hline
\end{tabular}

*: Yıl tarihi elde edilemeyen projeler dahil edilmemiştir.

büyüklükleri 0,5 hektar ile 140,62 hektar arasında değişkenlik göstermektedir (Bkz. Ek- Bütünleştirilmiş Tablo). Dönüşüm alanları niteliğine bakıldığında; gecekondu alanları, kaçak yapılaşmış alanlar, riskli yapılar dönüşüm kapsamındayken, aynı zamanda rezerv alanlar dışında bazı yapılaşmamış alanlarda dönüşüm sınırları içerisine alınmıştır (Bkz. Ek- Bütünleştirilmiş Tablo).

İstanbul Çevre Düzeni Planı ve değişikleri incelendiğinde; dönüşüm alanlarının planlama üzerindeki gücü daha görünür hale gelmektedir. İlk olarak 2012 yılında çıkarılan 6306 sayılı Afet
Tablo 5. Kentsel dönüşüm alan büyüklükleri ilçelere göre dağıııı*

\begin{tabular}{|c|c|c|}
\hline İlçe adı & Büyüklük (hektar) & Yüzde \\
\hline Bahçelievler & 0,25 & 0 \\
\hline Bağcılar & 64,37 & 2,9 \\
\hline Bakırköy & 3,2 & 0,1 \\
\hline Bayrampaşa & 23 & 1 \\
\hline Başakşehir & 54 & 2,4 \\
\hline Beşiktaş & 3,19 & 0,1 \\
\hline Beykoz & 5,6 & 0,3 \\
\hline Beyoğlu & 14,24 & 0,6 \\
\hline Büyükçekmece & 4,8 & 0,2 \\
\hline Esenler & 233,68 & 10,4 \\
\hline Fatih & 317,2 & 14,2 \\
\hline Gaziosmanpaşa & 262,16 & $\mathrm{II}, 7$ \\
\hline Güngören & 58 & 2,6 \\
\hline Kadıköy & 135,68 & 6,1 \\
\hline Kartal & 45,84 & 2 \\
\hline Küçükçekmece & 22,94 & I \\
\hline Pendik & 145,64 & 6,5 \\
\hline Sancaktepe & 35,9 & $\mathrm{I}, 6$ \\
\hline Sarıyer & 180,84 & 8,1 \\
\hline Silivri & 5,09 & 0,2 \\
\hline Sultangazi & 32 & $\mathrm{I}, 4$ \\
\hline Şişli & 17 & 0,8 \\
\hline Tuzla & 218,15 & 9,7 \\
\hline Üsküdar & $\mathrm{I}, 77$ & 0,1 \\
\hline Zeytinburnu & 354,27 & 15,8 \\
\hline Toplam & $2238,8 I$ & 100 \\
\hline
\end{tabular}

*: Toplam oranındaki dengesizliği bozmaması için Yenişehir rezerv yapı alanı dahil edilmemiştir.

Yasasıyla ilan edilen İstanbul Yenişehir rezerv yapı alanlarıyla birlikte çevre düzeni planında değişikliğe gidilmiş ve alt ölçekli dönüşüm kararları üst ölçekli plan kararlarını etkilemiştir. Bu planlar ve değişikliklerden 15.06.2009 tarihinde onaylanan I//00.000 ölçekli İstanbul Çevre Düzeni Planı ve önceki düzenlemeler incelendiğinde; kentin çepere doğru büyümesinin sınırlandırıldığı anlaşılmaktadır (Eren ve Özçevik, 20।5, s.228). 2009 yılı Çevre Düzeni Planında mevcut kent makroformunun kuzeydeki ormanlara, su kaynaklarına karşı büyük bir tehdit oluşturduğu ve bu hassas ekosistemlerin korunması amacıyla kentin doğu-batı aksı ve Marmara Denizi boyunca sıçrayarak geliştirilmesi ve kentin kuzeye doğru gelişimin kontrol altına alınması kararı getirilmiştir. Ayrıca kuzey alanları doğa odaklı turizm alanı, ekolojik tarım alanı ve ekolojik turizm alanı olarak planlıdır. Ancak 07.03.2020 tarihinde onaylanan I//00.000 


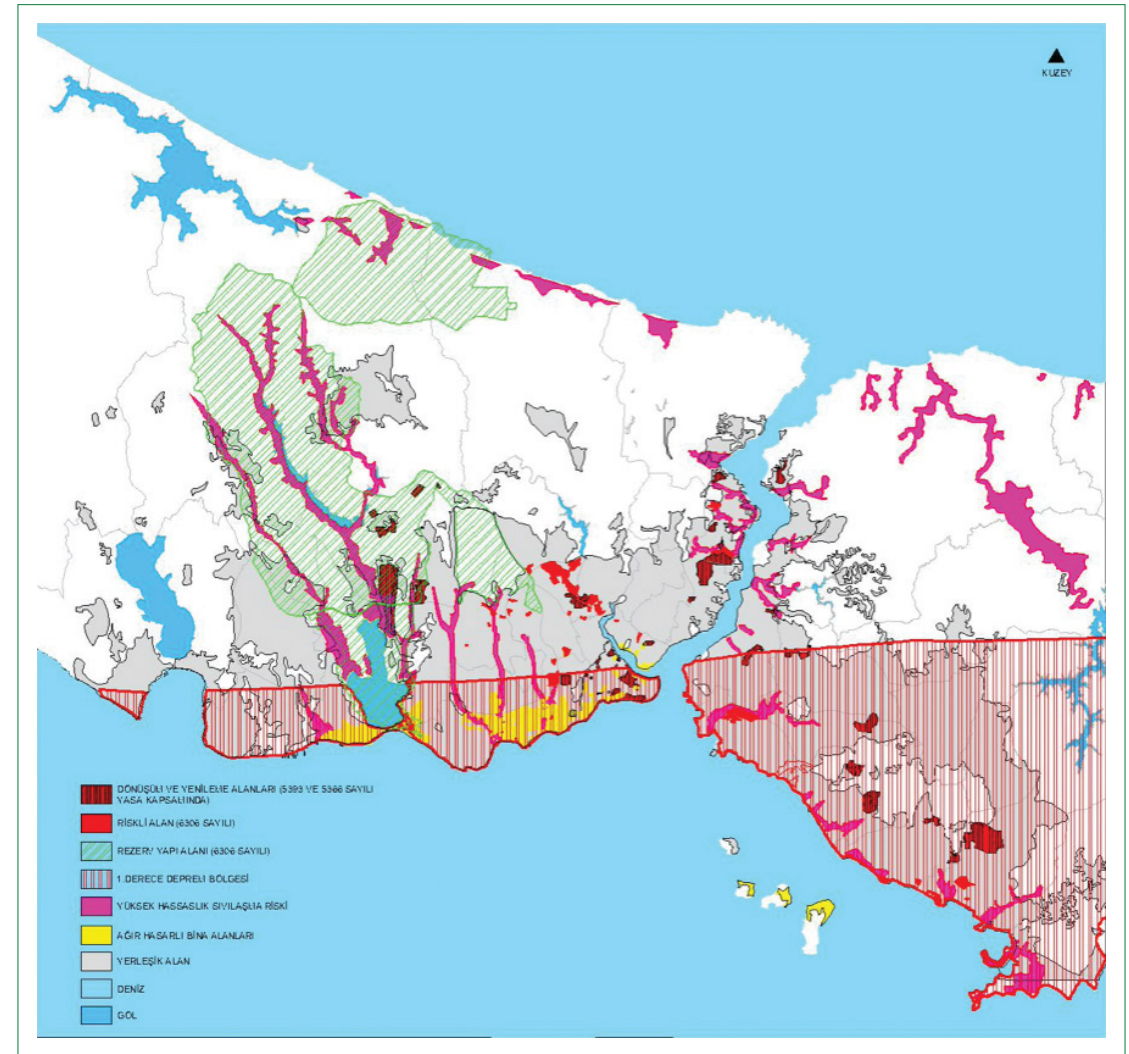

Şekil I. İstanbul genel kentsel dönüşüm alanları ve öncelikli riskli alanlar karşılaştırması.*

Öncelikli dönüşüm alanları; Japon Uluslararası İş birliği Ajansı-JICA Afet Önleme/Azaltma Temel Planı (2002) raporu, İstanbul Deprem Master Planı (2003), İstanbul Deprem Bölgeleri Haritası, İstanbul Kentsel Dönüşüm Master Planı Analiz verileri (20I6) dikkate alınarak belirlenmeye çalışılmıştır. Mevcut genel dönüşüm projeleri farklı aşamalarda ve kapsamı konular olması nedeniyle eksikliklerin olabileceği göz önünde bulundurulmalıdır. Kentsel dönüşüm sınırı iptal edilen veya kentsel dönüşüm kapsamından çıkarılan alanlar dahil edilmemiştir.

ölçekli Rezerv Yapı Alanı İstanbul Çevre Düzeni Planı Değişikliğinde (Kanal İstanbul Projesi) ise; Yenişehir olarak tarif edilen rezerv yapı alanları bölgesinde "ilkesel Makroform Tasarımı" ile kuzeye doğru kontrollü gelişim öngörmektedir. Kontrollü gelişim ile ekolojik açıdan hassas bölgelerdeki baskıyı azaltmak ve afet riskleri açısından sorunlu mevcut yerleşimlerdeki dönüşümü sağlamak için yapı ve nüfus yoğunluğunun düşük tutulması kararı getirilmiştir. Ancak yeni plan değişikliği ile kanal ve çevresini kapsayan plan sınırları dahilindeki tarım alanlarında \%52, 16 oranlık ${ }^{13}$ bir azalma görülmektedir. Ayrıca meri plana ilaveten yaklaşık 280 hektarlık ve 500.000 kişinin ${ }^{14}$ yaşayacağı bir alanın da kentsel gelişime açıldığı tespit edilmiştir (Kantarcı, 2019). Havza sınırları içerisinde belirli bir yoğunluk sınırının olması dönüşüm maliyet ve finansmanını daha da zor hale getirmektedir. İstanbul deprem senaryosuna göre olası bir deprem anında öncelikli riskli alanlar kuşkusuz en çok hasar görecek alanlardır. Dolayısıyla “öncelikli riskli alanların” dönüşüme alınmadığı bir uygulama sürecinde "afet risklerinin azaltılması” gerekçesinden uzaklaşıldığı görülmektedir. Ayrıca rezerv alan üzerinde inşa edilecek yeni şehirle birlikte gerçek konut gereksiniminin çok daha üzerinde bir konut sunumu gerçekleşecektir.

Japon Uluslararası İşbirliği Ajansı - JICA ve IBB (2002), İstanbul Deprem Master Planı (2003) ile Avrupa yakası (2007 yılı) ve Anadolu yakası (2009 yıı) mikro bölgeleme çalışmaları için farklı metotlar kullanılsa da, sonuç olarak sıvılaşma riski görülen alanlar birbirlerine oldukça benzemektedir. ${ }^{15}$ İstanbul geneli için en detaylı ve temel referanslardan biri olan JICA raporundan elde edilen verilere göre, yüksek hassaslı sıvılaşma riski bulunan ilçeler Avrupa yakasında Çatalca, Küçükçekmece, Eyüp, Anadolu yakasında ise, Kadıköy ve Bakırköy'dür (Bkz. Şekil I). Yine aynı raporda bina hasar görebilirlik ve felaket hasarlı bina durumları incelendiğinde; Avrupa yakasında Bakırköy (\%67), Zeytinburnu (\%62) ve Avcılar (\%44) İstanbul

\footnotetext{
${ }^{13}$ Kantarcı (2019) bu azalmanın bölgede satın alınmış olan tarım alanları tapularını kapsayabileceğini ve daha detaylı araştırma yapılması gerektiği belirtmiştir.

14 İstanbul ili Avrupa yakası rezerv yapı alanı I/I00.000 ölçekli İstanbul Çevre Düzeni Planı Değişikliği açıklama raporunda; planlama alanındaki mevcut nüfus 226.000 kişi olarak belirtilmiştir. Meri planlarla alanda öngörülen nüfus artışı 134.000 kişidir. Bu plan değişikliğiyle, meri planlarda belirlenen nüfus büyüklüğüne ilaveten en fazla 500.000 kişilik nüfus artışı öngörülmektedir. Sonuç olarak alanda 634.000 nüfusun geleceği planlanmakta ve mevcut 226.000 nüfusla birlikte planlama alanının toplam nüfusu 860.000 kişi olacaktır.

15 İstanbul Kentsel Dönüşüm Master Planı Analiz verileri, 2016.
} 
Tablo 6. Kentsel dönüşüm alan büyüklüklerinin ilçe yerleşik alan büyüklüğüne oranı*

\begin{tabular}{|c|c|c|}
\hline İlçe adı & Büyüklük (hektar) & Yüzde \\
\hline Bahçelievler & 0,25 & 0,02 \\
\hline Bağcılar & 64,37 & 2,90 \\
\hline Bakırköy & 3,2 & 0,11 \\
\hline Bayrampaşa & 23 & 2,41 \\
\hline Başakşehir & 54 & 1,52 \\
\hline Beşiktaş & 3,19 & 0,18 \\
\hline Beykoz & 5,6 & 0,13 \\
\hline Beyoğlu & 14,24 & 1,59 \\
\hline Büyükçekmece & 4,8 & 0,07 \\
\hline Esenler & 233,68 & 18,28 \\
\hline Fatih & 317,2 & 19,97 \\
\hline Gaziosmanpaşa & 262,16 & 22,46 \\
\hline Güngören & 58 & 8,09 \\
\hline Kadıköy & 135,68 & 5,44 \\
\hline Kartal & 45,84 & $\mathrm{I}, 52$ \\
\hline Küçükçekmece & 22,94 & 0,76 \\
\hline Pendik & 145,64 & 2,81 \\
\hline Sancaktepe & 35,9 & $\mathrm{I}, \mathrm{II}$ \\
\hline Sarıyer & 180,84 & 4,33 \\
\hline Silivri & 5,09 & 0,09 \\
\hline Sultangazi & 32 & $\mathrm{I}, 77$ \\
\hline Şişli & 17 & $\mathrm{I}, 03$ \\
\hline Tuzla & 218,15 & 4,28 \\
\hline Üsküdar & $\mathrm{I}, 77$ & 0,05 \\
\hline Zeytinburnu & 354,27 & 31,35 \\
\hline Toplam & 2238,81 & 100 \\
\hline
\end{tabular}

*: Toplam oranındaki dengesizliği bozmaması için Yenişehir rezerv yapı alanı dahil edilmemiştir.

geneli hasar görebilirlik ve felaket hasarlı olma oranları açısından öne çıkmaktadır. Bu oranı Asya yakası Marmara sahili Adalar (\%36) ilçesi takip etmektedir. Tarihi yarımada da ise, Eminönü (18), Fatih (\%/6), Beyoğlu (\%।3) öne çıkan ilçelerdir. Avrupa yakası bazı kısımlarında ise Küçükçekmece (\%/3), Bahçelievler (\%9) ve Bayrampaşa (\%9) felaket hasarlı ilçeler olarak belirlenmiştir. ${ }^{16}$

JICA Afet Önleme/Azaltma Temel Plan raporu (JICA ve IBB, 2002), İstanbul Deprem Master Planı (2003), İstanbul
Deprem Bölgeleri Dağılım Haritası, İstanbul Kentsel Dönüşüm Master Planı Analiz verileri (2016) üst üste değerlendirildiğinde; Avrupa yakasında zemin yapısı açısından yüksek hassaslı sıvılaşma ve heyelan riski, üzerinden yapılaşma açısından felaket hasarlı binaların yoğunlaştığı ve I. derece deprem bölgesinde bulunan Bakırköy, Zeytinburnu ve Avcılar ilçelerinin güney kısımları; Anadolu yakasında ise yüksek hassaslı sıvılaşma-heyelan riski ve I. derece deprem bölgesinde bulunan Kadıköy, Ataşehir, Maltepe, Kartal ve Pendik ilçelerinin güneybatı kısımları İstanbul genelinde birinci öncelikli ve doğrudan riskli alanlar olarak tespit edilmiştir (Bkz. Şekil I). Bu alanları felaket hasarlı binaların yoğunlaştığı ve I. derece deprem bölgesinde bulunan Fatih ilçesi takip etmektedir. Haritadan da izlenebildiği gibi, bu ilçelerin tamamının Marmara denizine kıyısı bulunmaktadır. Dolayısıyla tsunami riski ${ }^{17}$ de hesaba katıldığında bu ilçeler olası bir tehlike anında can ve mal kaybına neden olabilecek en korunmasız alanlardır ve kentsel dönüşümün öncelikli olarak uygulanması gereken yerlerdir. Ancak mevcut durumda genel kentsel dönüşüm alanları incelendiğinde, Bakırköy ve Fatih ilçelerinin bazı kısımlarında öncelikli riskli alanlar ile dönüşüm-yenileme alanları örtüşürken, büyük oranda uyuşmazlık bulunmaktadır. Benzer durum Başakşehir, Küȩükçekmece ve Sarıyer ilçelerinde de gözlenmektedir. Ancak harita genelinde "kentsel dönüşüm-gelişim alanları" ile "öncelikli dönüşüme" girmesi gereken alanlar arasında bir uyuşmazlık söz konusudur. Genel kentsel dönüşüm alanlarının birçoğu 2. ve 3. derece deprem bölgesinde bulunmaktadır. Ayrıca birçok riskli alanın zemin açısından yüksek risk içermeyen bölgelerde ilan edildiği anlaşılmaktadır (Bkz. Şekil I). 6306 sayılı Yasanın uygulama yönetmeliğinde; rezerv yapı alanları tanımından da anlaşılacağı gibi; rezerv yapı alanları, riskli alanlar ile bu alanlar dışındaki riskli yapılarda ikamet edenlerin taşınacağı yeni yerleşim alanlarıdır. Dolayısıyla yasada riskli alan ile riskli yapılarda oturanların rezerv yapı alanlarına nakledilerek, bu alanlar arasında doğrudan bir transfer ilişkisi kurulmuştur. Ancak İstanbul'da ilan edilen rezerv yapı alanları ile riskli alanlar arasında yasada tanımlandığı şekliyle doğrudan bir transfer ve koordinasyon ilişkisi bulunmamaktadır. Kentsel dönüşümün öncelikli hedefi riski alanların dönüşmesi iken, haritadan da izlenebildiği gibi mevcut uygulamaların çok sınırlı sayıda bu hedefe hizmet edebildiği görülmektedir. Mevcutta "genel kentsel dönüşüm alanları" "öncelikli riskli alanlar" yerine ekonomik nedenlerle, inşaat sektörü ve piyasa öncelikleri gibi risk dışındaki faktörlere göre şekillendiği söylenebilir. Nitekim bu durum İstanbul'da TOKi denetçilerin hazırladığı raporda da değinilen bir konudur. Bu rapora göre 76 yapının gerçekleştirilen plan tadilatları ve değişiklik-

\footnotetext{
16 AFAD'ın İstanbul depremi senaryosuna göre; 44.802 binanın yıkılacağı ve 2 milyon 374 bin kişinin açıkta kalacağı tahmin edilmektedir (https://www.haberturk.com/ marmara-depremi-icin-korkutan-senaryo-2 104243). Çevre ve Şehircilik Bakanlığı'ndan yapılan açıklamaya göre (2018), İstanbul'da yılda en az I00 bin konut olmak üzere, Türkiye genelinde yılda en az 300 bin konut, 2023'e kadar I milyon 500 bin gelecek yirmi yılda ise 6,7 milyon konut dönüştürülmesi hedeflenmektedir.

17 Tsunami riski İstanbul'da 50 yıl için \% I0'u aşma ihtimali ile kıyıdaki dalga yüksekliğine göre, Asya yakasında Kartal ile Tuzla arasında I00-300m kadar içeri girmesi beklenmektedir. Avrupa Yakasında ise Küçükçekmece gölü çevresinde 600 m kadar kara içine gireceği düşünülmektedir. Ayrıca yapay dolgu alanları da hesaba katıldı̆̆ında tsunamiden etkilenme oranlarının daha da artacağı beklenmektedir (İstanbul Kentsel Dönüşüm Master Planı Analiz verileri, 20।6, s.67).
} 
leriyle birlikte fazladan inşaat alanı işgal ettiğini ve 40 milyar dolarlık bir kazanç elde edildiğini göstermektedir. ${ }^{18}$ Özetle, genel kentsel dönüşüm uygulamaları kentlerin maruz kaldığı risklerin azaltılmasında etkin bir araç olarak kullanılamadığı; tarım alanları, ormanlık alanlar, su havzaları gibi hassas doğal alanların ${ }^{19}$ sürdürülebilirliğine yönelik herhangi bir önlem içermediği sonucunu göstermektedir.

\section{Sonuç}

Araştırma başında ortaya konan araştırma sorusu, araştırma sonuçları kapsamında değerlendirildiğinde, İstanbul'da dağınık halde bulunan genel kentsel dönüşüm alanlarının gerçek risk faktörü taşıyan öncelikli riskli alanlara göre oluşturulmadığı tespit edilmiştir. İstanbul'da "afet riski azaltımı, kentsel yaşam kalitesinin yükseltilmesi, sağlıklı ve güvenli yerleşim alanları” gibi gerekçelerle başlatılan genel kentsel dönüşüm alanlarının bu hedeflerle uygun olmadığı görülmektedir. Ayrıca kentsel dönüşüm ilanları sonrasında mevcut planlarda yapılan değişikliklerle birlikte, dönüşümün planlamaya alternatif bir seçenek olmadığını, aksine planlama üzerinde ciddi bir güce ulaştığını göstermektedir.

Genel kentsel dönüşüm alanları, artık İstanbul yerleşik alan sınırı büyüklüğünün \%32'sine (36.5 I I ha) ulaşmış durumdadır. Bu sınırlar alan araştırmasında görüldüğü gibi; bazen 0,5 hektar büyüklüğünde bir parsel, bazen de yaklaşık 34.273 hektar büyüklüğünde bir rezerv yapı alanı olabilmektedir. Ama daha önemlisi dönüşüm parçalarının neredeyse tamamının $(\% 97,19)$ sadece 6306 sayılı Afet Yasası kapsamında ilan edilmiş olmasıdır. Benzer şekilde afet yasasının çıktı̆̆ı 2012 yılından itibaren hem kentsel dönüşüm alan sayıları hem de alan büyüklükleri açısından önemli bir artış görülmektedir. Afet yasasının en temel hedeflerinden biri de "risk azaltımı"dır. Bu hedefle birlikte "öncelikli riskli alanlarda" afet risklerinin azaltılması ve afet risklerinden arındırılmış güvenli yerleşim alanlarının oluşturulması gerekmektedir. Ancak araştırma sonuçlarından da izlenebildiği gibi hem güvenli yerleşim alanlarını ifade eden rezerv yapı alanlarının risk faktörü taşıyan alanlarda (JICA Afet Önleme/Azaltma Temel Planı 2002 raporuna göre zemin açısından problemli) yer seçtiği hem de mevcut riskli alanların olası bir afet durumda ciddi can, mal ve çevresel kayıplara sebep olabilecek öncelikli riskli alanlara göre oluşturulmadığı görülmektedir. Bu durum kentin üst ölçekli plan kararlarını da zedelemektedir. Bir diğer dikkat çekilmesi gereken nokta ise, rezerv yapı alanları ile mevcut riskli alanlar arasında doğrudan bir transfer ilişkisinin kurulmamasıdır.

Günümüz kentlerinde gözlenen aşırı yağış, sel, taşkın, sıcaklık, kuraklık, sert tufanlar gibi olaylarda yaşanan hızlı ve sert değişimlerde şüphesiz yoğun, plansız kentleşme ve dengesiz arazi kullanımının büyük payı bulunmaktadır. İstanbul için önceki yapılan plan kararlarının birçoğunda kuzeye doğru gelişmenin sınırlandırıldığı görülmektedir. Ancak 07.03.2020 tarihinde onaylanan I/I00.000 ölçekli Rezerv Yapı Alanı İstanbul Çevre Düzeni Planı Değişikliğinde (Kanal İstanbul) önerilen Yenişehir rezerv yapı alanının büyük bölümü, büyük kentsel projelerle birleşmekte ve kuzeye doğru gelişim öngörmektedir. Genel dönüşüm-gelişim alanlarıyla nüfusu belirli bir dengeye ulaşan İstanbul için hem gerçek konut gereksiniminden çok daha fazla konut sunumu yapılacak, hem de orman, su havzaları, tarım alanları gibi doğal alanların sürdürülebilirliğine yönelik ciddi risklerle karşılaşılacaktır.

Piyasa öncülüğünde genel kentsel dönüşüm projeleriyle birlikte gelişen inşaat sektörü, mülk sahiplerinin, müteahhitlerin ve yöneticilerin kazanç beklentilerini yükseltmiştir. Dolayısıyla yatırım aracı olarak mülk sahibi olmanın cazip olmaktan çıkarılması gerekmektedir. ${ }^{20}$ Bir diğer önemli problem alanı ise, kentsel dönüşümle ilgili çıkarılan yasalardır. Yapılan dönüşüm uygulamaları yasal olduğu gerekçesiyle meşrulaştırılmaktadır. Genel kentsel dönüşüm yasalarında; sonuçtan çok sebeplere odaklanılması, sadece fiziksel düzenlemeleri değil, kentlerin mekânsal, sosyal ve ekonomik kırılganlıklarına ilişkin önlemler alacak şekilde revize edilmesi gerekmektedir. Ayrıca dönüşüm yasalarının planlama üzerinde bir güç oluşturması yerine, üst ölçekten alt ölçeğe kadar plan kademesiyle birlikte ve uyumlu ilerlemesi gerekmektedir. Dolayısıyla öncelikli yapılması gereken kentlerin çoklu tehlikelere ${ }^{21}$ karşı sosyal, ekonomik ve mekânsal kırılganlıklarının belirlenmesi ve bu kırılganlıklara karşı kentsel dayanıklılığının arttırılarak hasar görebilirliklerinin minimuma indirilmesi olacaktır. ${ }^{22}$

\footnotetext{
${ }^{18} \mathrm{https} / /$ www.gazetedamga.com.tr/manset-haber/istanbul-ranta-kurban-gitti-40-milyar-dolarlik-vurgun-h I 4665.html

19 07.03.2020 tarihinde onaylanan I//00.000 ölçekli Rezerv Yapı Alanı İstanbul Çevre Düzeni Planı Değişikliğinde; her ne kadar ekolojik açıdan hassas bölgelerdeki baskıyı azaltmak ve afet riskleri açısından sorunlu mevcut yerleşimlerdeki dönüşümü sağlamak için yapı ve nüfus yoğunluğunun düşük tutulması kararı getirilse de tarım alanlarında \%52, 16 oranlık bir azalma görülmektedir. Ayrıca meri plana ilaveten yaklaşık 280 hektarlık alanın kentsel gelişime açıldığı tespit edilmiştir İmara açılan alanların \%90,79'u otlak, \%8,59'u orman, \%0,62'si yerleşim kullanımındadır (Kantarcı, 2019).

${ }^{20}$ Bakanlık tarafından "Şehirlerde Rant Vergisi” sıkça dile getirilse de henüz uygulamaya konulamamıştır.

${ }^{21}$ Deprem, sel, heyelan, fırtına, tsunami, yangın, çevre kirliliği vb.

${ }^{22}$ Afet öncesi risk azalımına dayalı sakınım planlaması bu süreçte yapılması gereken ilk planlama adımı olmalıdır. Ayrıca afet sonrası insanların toplanabileceği, itfaiye, hastane, afet yönetim merkezi gibi hayati unsurlara toplanma ve erişim imkânı sağlayan yüksek erişilebilirlikte, yeterli büyüklükte toplanma alanları ve acil ulaşım yolları planlanmalıdır. Geçmişte acil ulaşım yolları ve toplanma alanları planlansa da, bunların mevcut kullanımları, büyüklükleri, olası bir afet durumunda kapanma riskleri (tsunami, sel, yangın, patlama vb.) düşünülerek yeniden gözden geçirilmelidir.
} 


\section{KAYNAKLAR}

5162 sayılı Toplu Konut Kanunu'nda ve Genel Kadro ve Usulü Hakkında Kanun Hükmünde Kararnamenin Eki Cetvellerin Toplu Konut İdaresi Başkanlığına Ait Bölümünde Değişiklik Yapılması Hakkında Kanun. (2004). Resmî Gazete (Sayı: 25460). Erişim adresi: https://www.tbmm. gov.tr/kanunlar/k5162.html

5366 sayılı Yıpranan Tarihi ve Kültürel Taşınmaz Varlıkların Yenilenerek Korunması ve Yaşatılarak Kullanılması Hakkında Kanun. (2005). Resmî Gazete (Sayı: 25866). Erişim adresi: https://www.mevzuat.gov.tr/MevzuatMetin/1.5.5366.pdf

5393 sayılı Belediye Kanunu. (2005). Resmî Gazete (Sayı: 25874). Erişim adresi: https://www.mevzuat.gov.tr/MevzuatMetin/1.5.5393.pdf

5998 sayılı Belediye Kanunu'nda Değişiklik Yapılmasına İlişkin Kanun. (2010). Resmî Gazete (Sayı: 27621). Erişim adresi: https://www.resmigazete.gov.tr/eskiler/2010/06/20100624-2.htm

6306 sayılı Afet Riski Altındaki Alanların Dönüștürülmesi Hakkında Kanun. (2012). Resmî Gazete (Sayı: 28309). Erişim adresi: https://www.mevzuat.gov.tr/mevzuat?Mevzuat $\mathrm{No}=6306 \&$ Mevzuat Tur $=1 \&$ MevzuatTer tip $=5$

775 sayılı Gecekondu Kanunu. (1966). Resmî Gazete (Sayı: 12362). Erişim adresi: https://www.mevzuat.gov.tr/MevzuatMetin/1.5.775.pdf

Altaban, Ö. (1998). Cumhuriyet' in Kent Planlama Politikaları ve Ankara Deneyimi. Yıldız Sey (Ed.), 75 yılda Değişen Kent ve Mimarlık içinde (s. 41-64). İstanbul: Tarih Vakfi Yayınları.

Amin, A., Thrift, N. (2007). Cultural-Economy and Cities. Progress in $\mathrm{Hu}-$ man Geography, 31(2), 143-161.

Andersson, R., Brama, A., Holmqvist, E. (2010). Counteracting Segregation: Swedish Policies and Experiences. Housing Studies, 25(2), 237-256.

Arbaci, S. (2007). Ethnic Segregation, Housing Systems and Welfare Regimes in Europe. European Journal of Housing Policy, 7(4), 401-433.

Ataöv, A., Osmay, S. (2007). Türkiyéde Kentsel Dönüşüme Yöntemsel Bir Yaklaşım. METU, JFA, 24(2), 57-82.

Bartu Candan, A., Kolluoğlu, B. (2008). Emerging Spaces of Neoliberalism: A Gated Town and a Public Housing Project in Istanbul. New Perspectives on Turkey, 39, 5-46.

Bayındırlık ve İskân Bakanlığı. (1996). Türkiye Deprem Bölgeleri Haritası. İstanbul Altyapı ve Kentsel Dönüşüm Hizmetleri Müdürlüğü (Güncelleyen), İstanbul Deprem Bölgeleri Dağılımı Haritası.

Bektaş, Y. (2014). Bir Kentleşme Stratejisi Olarak Yasanın Kentsel Mekanı Dönüștürmedeki Etkisi: Ankara Örneği. Planlama,24(3), 157-172.

Duman, B., Coşkun, İ. (2015). Kentsel Dönüşüm: Temel Meseleler Üzerine. Betül Duman ve İsmail Coşkun (Ed.), Neden Nasıl ve Kim İçin, Kentsel Dönüşüm içinde (s.21-52). İstanbul: Litera Yayıncllk.

Eraydin, A. (2008). The Impact of Globalisation on Different Social Groups: Competitiveness, Social Cohesion and Spatial Segregation in Istanbul. Urban Studies, 45(8), 1663-1691.

Eren, M. Ö., Özçevik, Ö. (2015). Institutionalization of disaster risk discourse in reproducing urban space in Istanbul. ITU AZ, 12(1), 221-241.

Erman, T. (2016). Mış Gibi Site, Ankara'da Bir TOKİ-Gecekondu Dönüşüm Sitesi. İstanbul: İletişim Yayınları.

Fainstein, S.S. (2005). Cities and Diversity Should We Want It? Can We Plan For It?. Urban Affairs Review, 41(1), 3-19.

Fainstein, S.S. (2008). Mega-Projects in New York, London and Amsterdam. International Journal of Urban and Regional Research, 32(4), 768-785.

Güzey, Ö. (2015). The Last Round in Restructuring the City: Urban Regeneration Becomes a State Policy of Disaster Prevention in Turkey. Cities, 50, 40-53.

Harvey, D. (1989). From Managerialism to Entrepreneurialism: The Transformation in Urban Governance in Late Capitalism. Human Geography, 71(1), 3-17.

Hirst, P., Zeitlin, J., (1991). Flexible Specialization Versus Post-Fordism: The- ory, Evidence and Policy Implications. Economy and Society, 20(1), 1-56. http://www.hurriyet.com.tr/gundem/son-dakika-ituden-son-dakikaistanbul-depremi-aciklamasi-41338687, erişim tarihi: Eylül, 2019

http://www.milliyet.com.tr/kurulan-yabanci-ortakli-sirket-ekonomi-2814515/, erişim tarihi: Eylül, 2019

http://www.mimarlikdergisi.com/index.cfm?sayfa $=$ mimarlik $\&$ DergiSayi $=4$ 07\&RecID=4095, erişim tarihi: Eylül, 2019

http://www.sbb.gov.tr/yatirimlarin-illere-gore-dagilimi/erişim tarihi: Mayıs, 2020

https://www.gazetedamga.com.tr/manset-haber/istanbul-ranta-kurbangitti-40-milyar-dolarlik-vurgun-h14665.html, erişim tarihi: Eylül, 2019

https://www.haberturk.com/marmara-depremi-icin-korkutan-senaryo-2104243, erişim tarihi: Ağustos, 2018.

Işık, O., Pınarcıoğlu, M. (2009). İstanbul'da Kentsel Ayrışma: 1990'dan 2000'e Neler Oldu?. Serap Kayasü, Oğuz Işsk, Nil Uzun, Ebru Kamacı (Ed.), Gecekondu Dönüşüm, Kent içinde (s.379-407). Ankara: ODTÜ Mimarlık Fakültesi Basım İşliği.

İBB. (2003). İstanbul İçin Deprem Master Planı. İstanbul Büyükşehir Belediyesi Planlama ve İmar Dairesi Zemin ve Deprem İnceleme Müdürlüğü, İstanbul.

İBB. (2016). İstanbul İl Bütünü için Kentsel Dönüşüm Perspektifiyle Hazırlanacak Planlara Altlık Teşkil Edecek Analitik Veri Hazırlama İşi Kapsamında-6.1.1. Mevcut Durum ile İlgili Analizler. Deprem Risk Yönetim ve Kentsel İyileştirme Daire Başkanlığı Kentsel Dönüşüm Müdürlüğü, İstanbul.

İslam, T., Enlil, Z. (2010). 5366 Sayılı Yasa Merkezli Dönüşüm ve Sulukule Örneği: Belediyénin Hedefleri ve Yaşanan Gerçeklik. Dilek Özdemir (Ed.), Kentsel Dönüşümde Politika, Mevzuat, Uygulama: Avrupa Deneyimi, İstanbul Uygulamaları içinde (s. 317-334). Ankara: 1. Baskı, Nobel Yayın.

İstanbul İli Avrupa Yakası Rezerv Yapı Alanı 1/100.000 ölçekli İstanbul Çevre Düzeni Planı Değişikliği Plan Açıklama Raporu, (2019). T.C. Çevre ve Şehircilik Bakanlığı Mekânsal Planlama Genel Müdürlüğü, erişim adresi: https://mpgm.csb.gov.tr/istanbul-ili-avrupa-yakasi-rezerv-yapi-alani-1100.000-olcekli-cevre-duzeni-plani-degisikligi-i- 98680

JİCA ve İBB (2002). Türkiye Cumhuriyeti İstanbul İli Sismik Mikro-Bölgeleme Dahil Afet Önleme/Azaltma Temel Plan Çalışması (Final Rapor No: 5). Pacific Consultants International OYO Corporation.

Kantarc1, M.D. (2019). Karadeniz-Marmara Denizi Kanalı́nın (İstanbul Kanalı) Yakın Çevresine Yapacağı Etkiler Hakkında Ekolojik Değerlendirmeler. İstanbul Barosu Çevre, Kent ve İmar Hukuku Komisyonu ve Cumhuriyet Araştırmaları Merkezi (Ed.), Kanal İstanbul'un Çevresel ve Hukuki Etkileri (Montreux Sözleşmesi) içinde (s.49-110). İstanbul: İstanbul Barosu Yayınları

KPMG (2019). İnşaat Sektörel Bakış Raporu, erişim adresi: https://home. $\mathrm{kpmg} / \mathrm{tr} / \mathrm{tr} /$ home/gorusler/2019/01/sektorel-bakis-2019-insaat.html

Loftman, P., Nevin, B. (1995). Prestige Projects and Urban Regeneration in the 1980s and 1990s: A Review of Benefits and Limitations. Planning Practice \& Research, 10(3-4), 299-316.

Montgomery, J. (2003). Cultural Quarters as Mechanisms for Urban Regeneration. Part 1: Conceptualising Cultural Quarters. Planning, Practise \& Research, 18(4), 293-306.

Öktem Ünsal, B., Türkün, A. (2014). Neoliberal Kentsel Dönüşüm, Kentsel Alanlarda Sınıfsal Tahliye, Yoksullaşma ve Mülksüzleșme. Asuman Türkün (Ed.), Mülk, Mahal, İnsan: İstanbul'da Kentsel Dönüşüm içinde (s.17-42). İstanbul: İstanbul Bilgi Üniversitesi Yayınları.

Öktem, B. (2006). Neo-Liberal Küreselleşmenin Kentlerde İnșası: AKP'nin Küresel Kent Söylemi ve İstanbul'un Kentsel Dönüşüm Projeleri. Planlama Dergisi, 36, 53-64.

Özdemir, D. (2010). Kentsel Dönüşüm Olgusunun Süreç İçinde Değişen Anlamları. Dilek Özdemir (Ed.), Kentsel Dönüşümde Politika, Mevzuat, Uygulama: Avrupa Deneyimi, İstanbul Uygulamaları içinde (s.1-31). 
Ankara: Nobel Yayın.

Peck, J. (2005). Struggling with the Creative Class. International Journal of Urban and Regional Research, 29(4), 740-770.

Pratt, A.C. (2008). Cultural Commodity Chains, Cultural Clusters, or Cultural Production Chains?. Growth and Change, 39(1), 95-103.

Roberts, B.R. (2005). Globalization and Latin American Cities. International Journal of Urban and Regional Research, 29(1), 110-123.

Scott, A.J. (2006). Creative Cities: Conceptual Issues and Policy Questions. Journal of Urban Affairs, 28(1), 1-17.

Sey, Y. (1998a). Cumhuriyet Döneminde Türkiyéde Mimarlık ve Yapı Üretimi. Yıldız Sey (Ed.), 75 yılda Değişen Kent ve Mimarlık içinde (s. 25-39). İstanbul: Tarih Vakfi Yayınları.

Sey, Y., (1998b). Cumhuriyet Döneminde Konut. Yıldız Sey (Ed.), 75 yılda Değişen Kent ve Mimarlık içinde (s. 273-300). İstanbul: Tarih Vakf, Yayınları.

Sezgin, A.Ş. (2018). İnşaat sektörü, İktisadi Araştırmalar bölümü, Türkiye İş Bankas1

Slater, T. (2006). The Eviction of Critical Perspectives from Gentrification Research, International Journal of Urban and Regional Research, 30(4), 737-757.

Smith, N. (2002). New Globalism, New Urbanism: Gentrification as Global Urban Strategy. Antipode, 34, 427-449; Urkun-Bowe, İ. ve Gündoğdu, İ. (Çev.). (2006). Yeni Küresellik, Yeni Şehircilik: Küresel Kentsel Strateji Olarak Soylulaștırma. Planlama Dergisi, 36, 13-27.

Swyngedouw, E., Moulaert, F., Rodriguez, A. (2002). Neoliberal Urbanization in Europe: Large-Scale Urban Development Projects and the New Urban Policy. Antipode, 34(3), 547-577.

Şahin, S.Z. (2006). Kentsel Dönüșümün Kentsel Planlamadan Bağımsızlaştırılması/Ayrilması Sürecinde Ankara. Planlama Dergisi, 36, 111-120.

Şen, B. (2005). Soylulaştırma: Kentsel Mekânda Yeni Bir Ayrışma Biçimi. Hatice Kurtuluş (Ed.), İstanbul'da Kentsel Ayrışma içinde (s. 127-159). İstanbul: 1. Basım, Bağlam Yayınları.

Şenyapilı, T. (1998). Cumhuriyet' in 75. Y1l Gecekondunun 50. Y1l1. Y1ldız Sey (Ed.), 75 yılda Değişen Kent ve Mimarlık içinde (s. 301-316). İstanbul: Tarih Vakfi Yayınları.

Şenyapilı, T. (2004). Baraka’dan Gecekonduya Ankara'da Kentsel Mekânın Dönüşümü: 1923-1960. İstanbul: İletişim Yayınları.

T.C. Çevre ve Şehircilik Bakanlığı (2018), "Kentsel Dönüşüm Eylem Planı açıklaması”, erişim adresi: https://csb.gov.tr/kentsel-donusum-eylemplani-aciklandi-bakanlik-faaliyetleri-28602

Tallon, A.R. (2010). İngiltere'de Kentsel Rönesans: Kentlerdeki Yansımaları ve Eleştirel Değerlendirmeler. Dilek Özdemir (Ed.), Kentsel Dönüşümde Politika, Mevzuat, Uygulama: Avrupa Deneyimi, İstanbul Uygulamaları içinde (s.79-97). Ankara: Nobel Yayın.

Taşan-Kok, T. (2010). Entrepreneurial Governance: Challenges of Large-scale Property-Led Urban Regeneration Projects. Tijdschrift Voor Economische En Sociale Geografie, 101, 126-149.

Tekeli, İ. (2003). Kentleri Dönüşüm Mekânı Olarak Düşünmek. Pelin Pınar Özden, İlknur Karakaş, Sırma Turgut, Hülya Yakar, Demet Erdem, Neslihan Palaoğlu (Ed.), Kentsel Dönüşüm Sempozyumu Bildiriler içinde (s.2-7). İstanbul: YTÜ.

Tekeli, İ. (2013). “İstanbul: Siyaset, Ekonomi, Mekân”, Prof. Dr. Kemali Saybaşlı Anısına Sempozyumu YTÜ, 12 Nisan 2013, İstanbul.

Tekeli, İ. (1998). Türkiyéde Cumhuriyet Döneminde Kentsel Gelişme ve Kent Planlaması. Yıldız Sey (Ed.), 75 yılda Değişen Kent ve Mimarlık içinde (s. 1-24). İstanbul: Tarih Vakfi Yayınları.

Terzi, F. (2018). “Üst Ölçekli Planlama Deneyimleri” konulu panelde AGÜ’de yaptığı konuşması, 13 Aralık 2017.

TMMOB, Mimarlar Odası, (2008). TOKİ Raporu, http://www.mo.org.tr/ belgedocs/toki-rapor-2.pdf, 6 Aralık 2016.

TOKİ. (2011). Gecekondu Dönüşüm Kentsel Yenileme Projeleri. Toplu Konut İdaresi Başkanlığı, Ankara: Matsa Basımevi.
Turok, I. (2004). Cities, Regions and Competitivences. Regional Studies, 38(9), 1069-1083.

Türkün, A., (2015). Kentsel Dönüşümü Yeniden Düşünmek: Mevcut Uygulamalar ve Hâkim Söylem Üzerinden Bir Değerlendirme. Betül Duman ve İsmail Coşkun (Ed.), Neden Nasıl ve Kim İçin, Kentsel Dönüşüm içinde (s.285-332). İstanbul: Litera Yayıncıllk.

Türkün, A., Aslan, Ş. ve Şen, B. (2014a). 1923-1980 Döneminde Kentsel Politikalar ve İstanbul'da Konut Alanlarının Gelişimi: Mevzuat, Aktörler ve Hâkim Söylem. Asuman Türkün (Ed.), Mülk, Mahal, İnsan: İstanbul'da Kentsel Dönüşüm içinde (s.45-78). İstanbul: İstanbul Bilgi Üniversitesi Yayınları.

Türkün, A., Kurtuluş, H. (2005). Giriş. Hatice Kurtuluş (Ed.), İstanbul'da Kentsel Ayrışma içinde (s.9-24). İstanbul: Bağlam Yayınları.

Türkün, A., Öktem Ünsal, B., Yapıc1, M. (2014b). 1980’ler Sonrasinda İstanbul'da Kentsel Dönüşüm: Mevzuat, Söylem, Aktörler ve Dönüşümün Hedefindeki Alanlar. Asuman Türkün (Ed.), Mülk, Mahal, İnsanİstanbul'da Kentsel Dönüşüm içinde (s.79-139). İstanbul: İstanbul Bilgi Üniversitesi Yayınları.

Türkün, A., Yapıcı, M. (2009). Kentsel Dönüşüm ve Yasaların Araçsallaşan: Rolü Sermaye Birikimi Açısından Kentsel Dönüşüm, İktisat Dergisi, 499, 48-58.

Türkün-Erendil, A., Ulusoy, Z. (2002). Reinvention of Tradition as an Urban Image: The Case of Ankara Citadel, Environment and Planning B: Planning and Design, 29, 655-672.

Uzun, N. (2006). Kentsel Dönüşümde Yeni Bir Kavram: Seçkinleştirme. Ayda Eraydın (Ed.), Değişen Mekân içinde (s. 340-360), Ankara: Dost Kitabevi Yayınları.

Weber, R. (2002). Extracting Value from the City: Neoliberalism and Urban Redevelopment. Antipode, 34(3), 519-540.

www.toki.gov.tr/haber, 2018, erişim tarihi: eylül, 2018

Yalçıntan, M.C., Çalışkan, Ç.A, Çılgın, K., Dündar, U. (2014). İstanbul Dönüşüm Coğrafyası. Ayfer Bartu Candan ve Cenk Özbay (Ed.), Yeni İstanbul Çalışmaları Sınırlar, Mücadeleler, Açılımlar içinde (s.47-70). İstanbul: Metis Yayınları. 


\section{EKLER}

Ek I. Bütünleştirilmiş tablo*

\begin{tabular}{|c|c|c|c|c|c|}
\hline $\begin{array}{l}\text { Yasa } \\
\text { numarası }\end{array}$ & $\begin{array}{l}\text { İlan } \\
\text { yılı }\end{array}$ & Bölge adı & Mahalle adı & $\begin{array}{l}\text { Büyüklük } \\
\text { (hektar) }\end{array}$ & $\begin{array}{l}\text { Mevcut } \\
\text { durum }\end{array}$ \\
\hline 6306 & 2019 & $\begin{array}{l}\text { Arnavutköy, } \\
\text { Avcılar, } \\
\text { Başakşehir, } \\
\text { Küçükçekmece }\end{array}$ & Yenişehir Rezerv Yapı Alanı & $34.272,19$ & $\begin{array}{l}\text { Mevcut Durum } \\
\text { Planlama çalışmaları devam } \\
\text { etmektedir. }\end{array}$ \\
\hline 6306 & 2018 & Bahçelievler & Zafer Mah. Ahmet Yesevi Cad. üzeri & 0,25 & (6 adet kaçak yapı) Rezerv Alan \\
\hline 6306 & 2013 & Bağcılar & $\begin{array}{l}\text { Albayraklar Sitesi Riskli Alan } \\
\text { Çalışması }\end{array}$ & 3 & İnşaat yapım aşamasındadır. \\
\hline 6306 & - & Bağcılar & Bağcılar Meydan Riskli Alan Çalışması & 22 & Planlar iptal edilmiştir. \\
\hline 6306 & - & Bağcılar & Bağlar Mahallesi Riskli Alan Çalışması & 0,9 & Planlar hazırlanmaktadır. \\
\hline 6306 & 2013 & Bağcılar & $\begin{array}{l}\text { Çınar- İnönü - Sancaktepe - } \\
\text { Yavuzselim - Merkez }\end{array}$ & 22,08 & - \\
\hline 6306 & 2013 & Bağcılar & Demirkapı & 3,23 & - \\
\hline 6306 & 2013 & Bağcılar & Evren & 1,94 & - \\
\hline 6306 & 2013 & Bağcılar & Göztepe & 20,73 & Alan ve plan kararı iptal edilmiştir. \\
\hline 6306 & 2013 & Bağcılar & Kemalpaşa & 5,42 & Planlar hazırlanmaktadır. \\
\hline 6306 & - & Bağcılar & $\begin{array}{l}\text { Mahmutbey Mostar Köprüsü Riskli } \\
\text { Alan }\end{array}$ & 1,8 & Planlar hazırlanmaktadır. \\
\hline 6306 & - & Bağcılar & $\begin{array}{l}\text { THY Sitesi A ve C Bloklar Riskli } \\
\text { Alan Çalışması }\end{array}$ & 2,3 & Planlar hazırlanmaktadır. \\
\hline 6306 & 2013 & Bağcılar & $\begin{array}{l}\text { THY Sitesi B Bloklar Riskli Alan } \\
\text { Çalışması }\end{array}$ & $\mathrm{I}, 7$ & İnşaat yapım aşamasındadır \\
\hline 6306 & 2018 & Bakırköy & Şenlik & 3,2 & Rezerv Alan \\
\hline 6306 & 2013 & Bayrampaşa & Vatan & 23 & Riskli Alan \\
\hline 5393 & 2011 & Başakşehir & $\begin{array}{l}\text { Sıvat-Yeşiltepe kentsel dönüşüm ve } \\
\text { gelişim alanı }\end{array}$ & 54 & Büyük bir kısmı boş \\
\hline 6306 & 2013 & Beşiktaş & Etiler/Rumelihisarı (Akat) & 3,19 & - \\
\hline 6306 & 2018 & Beykoz & Çubuklu Mahallesi & 5,6 & Riskli alan \\
\hline 5366 & 2005 & Beyoğlu & Tarlabaşı & 2 & - \\
\hline 6306 & 2012 & Beyoğlu & İstiklal & 9,22 & - \\
\hline 6306 & 2012 & Beyoğlu & Örnektepe - Sütlüce & 3,02 & - \\
\hline 6306 & 2018 & Büyükçekmece & Mimarsinan & 4,8 & Riskli Alan \\
\hline 6306 & 2012 & Esenler & Atışalan Havaalanı & 7,32 & - \\
\hline 6306 & 2013 & Esenler & Çiftehavuzlar & 8,29 & - \\
\hline 6306 & & Esenler & Çiftehavuzlar & 9,5 & Rezerv Alan/Büyük çoğunluğu boş \\
\hline 6306 & 2013 & Esenler & Oruçreis I & 7,26 & - \\
\hline 6306 & 2013 & Esenler & Oruçreis 2 & 5,11 & - \\
\hline 6306 & 2017 & Esenler & Oruçreis & I & Rezerv Alan/Boş \\
\hline 6306 & 2012 & Esenler & Tuna & 2,56 & - \\
\hline 6306 & 2015 & Esenler & Tuna & 1,64 & $\begin{array}{l}\text { Rezerv Alan/Mevcut Yapı (sosyal tesis, } \\
\text { rekreasyon alanı, kültür merkezi) }\end{array}$ \\
\hline
\end{tabular}


Ek I (devamı). Bütünleştirilmiş tablo*

\begin{tabular}{|c|c|c|c|c|c|}
\hline $\begin{array}{l}\text { Yasa } \\
\text { numarası }\end{array}$ & $\begin{array}{l}\text { İlan } \\
\text { yılı }\end{array}$ & Bölge adı & Mahalle adı & $\begin{array}{l}\text { Büyüklük } \\
\text { (hektar) }\end{array}$ & $\begin{array}{l}\text { Mevcut } \\
\text { durum }\end{array}$ \\
\hline 6306 & - & Esenler & Güney (Metris) Alanı & 191 & $\begin{array}{l}\text { Rezerv Alan/Kışla-binalar; büyük } \\
\text { çoğunluğu boş }\end{array}$ \\
\hline 5366 & - & Fatih & Ayvansaray & 2 & Sivil Mimarlık, Anıteser \\
\hline 5366 & - & Fatih & $\begin{array}{l}\text { Yedikule-Yenikapı Sahil Şerdi II. Etap } \\
\text { Yenileme Alanı (Samatya Mevkii) }\end{array}$ & 15 & $\begin{array}{l}\text { Kentsel ve tarihi sit, kentsel } \\
\text { arkeolojik sit ve Sur-u Sultan'ın içi } \\
\text { I. Derece Arkeolojik Sit }\end{array}$ \\
\hline 5366 & - & Fatih & $\begin{array}{l}\text { Küçük Mustafa Paşa ve Haraççı Kara } \\
\text { Mehmet Mahalleleri (Unkapanı) } \\
\text { Yenileme Alanı }\end{array}$ & 8,3 & $\% 16$ 'sı tescilli bina \\
\hline 5366 & 2006 & Fatih & Fener-Balat & 28 & Sivil Mimarlık, Anıteser \\
\hline 5366 & 2005 & Fatih & Davutpaşa-Bulgur Palas & 3,9 & Sivil Mimarlık, Anıteser \\
\hline 5366 & 2005 & Fatih & Neslişah ve Hatice Sultan (Sulukule) & 9,2 & Sivil Mimarlık, Anıteser \\
\hline 5366 & - & Fatih & Süleymaniye Bölgesi & 92 & Sivil Mimarlık, Anıteser \\
\hline 5366 & - & Fatih & $\begin{array}{l}\text { Yedikule-Yenikapı Sahil Şerdi III. Etap } \\
\text { Yenileme Alanı }\end{array}$ & 52 & Sivil Mimarlık, Anıteser \\
\hline 5366 & - & Fatih & Kapalı Çarşı & 10,9 & - \\
\hline 5366 & - & Fatih & $\begin{array}{l}\text { Hüsambey, Kırkçeşme ve Şeyh Resmi } \\
\text { Mahalleleri }\end{array}$ & 7,4 & Sivil Mimarlık, Anıteser \\
\hline 5366 & - & Fatih & $\begin{array}{l}\text { Nişanca Sultanahmet I. Etap } \\
\text { Yenileme Alanı }\end{array}$ & 78 & - \\
\hline 5366 & 2012 & Fatih & Beyazıtağa, Ereğli Mahallesi & 10,5 & - \\
\hline 6306 & & Gaziosmanpaşa & Bağlarbaşı & 16,42 & - \\
\hline 6306 & 2012 & Gaziosmanpaşa & $\begin{array}{l}\text { Barbaros Hayrettin Paşa- } \\
\text { Karadeniz-Karayolları (IOA-IOB) }\end{array}$ & 158,25 & Dava sonucunda iptal edildi. \\
\hline 6306 & - & Gaziosmanpaşa & Karayolları Mahallesi I. Kısım (I0C) & 21,55 & - \\
\hline 6306 & 2012 & Gaziosmanpaşa & Kazım Karabekir - Fevzi Çakmak & 59,33 & - \\
\hline 6306 & 2012 & Gaziosmanpaşa & Mevlana Mahallesi & 38,24 & Temyiz süreci devam ediyor. \\
\hline 6306 & - & Gaziosmanpaşa & Mevlana Mahallesi I. Kısım-IIA & 7,17 & Bina \\
\hline 6306 & 2012 & Gaziosmanpaşa & Pazariçi Güney & 18,80 & Bina \\
\hline 6306 & 2012 & Gaziosmanpaşa & Pazariçi Kuzey & 16,67 & Bina \\
\hline 6306 & - & Gaziosmanpaşa & Sarıgöl Mahallesi I2B I. Etap & 3,31 & Bina \\
\hline 6306 & - & Gaziosmanpaşa & Sarıgöl Mahallesi I2C & 4,84 & Bina \\
\hline 6306 & - & Gaziosmanpaşa & Yeni Mahalle & 10,91 & Bina \\
\hline 6306 & - & Gaziosmanpaşa & Yıldıztabya Bölge 5 & 14,16 & - \\
\hline 6306 & - & Gaziosmanpaşa & Yıldıztabya Bölge 5-6A & 21,85 & Teklif aşamasında \\
\hline 6306 & - & Gaziosmanpaşa & Yıldıztabya Bölge 2. Kısım 6B Bölgesi & 16,86 & Bina \\
\hline 6306 & - & Gaziosmanpaşa & Yenidoğan Mahallesi I. Kısım & 7,11 & Bina \\
\hline 6306 & - & Gaziosmanpaşa & Merkez & 4,94 & Bina I57 Bina; 57I Bağımsız Bölüm \\
\hline 6306 & - & Gaziosmanpaşa & Bağlarbaşı Mahallesi Ek Bölge-I3 & 7,56 & Dava sonucunda iptal edildi. \\
\hline 5393 & 2009 & Güngören & $\begin{array}{l}\text { Tozkoparan Gecekondu Önleme } \\
\text { Bölgesi Gecekondu Dönüşüm/ } \\
\text { Kentsel Yenileme Alanı }\end{array}$ & 58 & $\begin{array}{l}5000 \text { kat mülkiyetli, } 500 \text { kadar da } \\
\text { kaçak veya gecekondu olmak üzere } \\
\text { yaklaşık } 5500 \text { bağımsız konut }\end{array}$ \\
\hline
\end{tabular}


Ek I (devamı). Bütünleştirilmiş tablo*

\begin{tabular}{|c|c|c|c|c|c|}
\hline $\begin{array}{l}\text { Yasa } \\
\text { numarası }\end{array}$ & $\begin{array}{l}\text { İlan } \\
\text { yılı }\end{array}$ & Bölge adı & Mahalle adı & $\begin{array}{l}\text { Büyüklük } \\
\text { (hektar) }\end{array}$ & $\begin{array}{l}\text { Mevcut } \\
\text { durum }\end{array}$ \\
\hline 6306 & 2013 & Güngören & $\begin{array}{l}\text { Tozkoparan Gecekondu Önleme } \\
\text { Bölgesi içindeki alan }\end{array}$ & 57,71 & Dava sonucunda iptal edildi. \\
\hline 6306 & 2013 & Kadıköy & $\begin{array}{l}\text { Fikirtepe-Eğitim-Dumlupınar ve } \\
\text { Merdivenköy }\end{array}$ & 134,18 & Riskli alan \\
\hline 6306 & - & Kadıköy & Sahrayı Cedit & $\mathrm{I}, 5$ & Riskli alan \\
\hline 6306 & - & Kadıköy & İlçe geneli & & 3592 riskli bina \\
\hline 6306 & 2013 & Kartal & Yukarı Mahalle & 10,91 & - \\
\hline 6306 & 2013 & Kartal & Kordonboyu & 3,11 & - \\
\hline 6306 & 2013 & Kartal & Yunus & 17,82 & Bina \\
\hline 6306 & 2013 & Kartal & Batı Merkez & 14 & I I 2 bina, 2453 bağımsız bölüm \\
\hline 6306 & 2013 & Küçükçekmece & Fatih & 7,41 & - \\
\hline 6306 & 2013 & Küçükçekmece & Kanarya & 9,23 & - \\
\hline 6306 & - & Küçükçekmece & İkitelli Atatürk Mahallesi & 6,3 & - \\
\hline 6306 & 2016 & Pendik & Batı & 54,32 & $\begin{array}{l}2000 \text { yılı öncesi inşa edilmiş } 465 \text { adet } \\
\text { binadan oluşmaktadır. \%65,37'si imar } \\
\text { mevzuatına aykırı }\end{array}$ \\
\hline 6306 & 2017 & Pendik & Dumlupınar - Orta & 91,32 & 2000 yılı öncesi imara aykırı binalar \\
\hline 5393 & 2017 & Sancaktepe & Hilal Mahallesi & 20,3 & Gecekondu-kaçak yapılaşma \\
\hline 5393 & 2018 & Sancaktepe & Fatih Mahallesi & 15,6 & Gecekondu-kaçak yapılaşma \\
\hline 6306 & 2013 & Sariyer & Ferahevler Mahallesi & 12,25 & Rezerv Alan \\
\hline 6306 & 2017 & Sarıyer & Çamlıtepe (Derbent) & 27,97 & Riskli alan \\
\hline 6306 & 2016 & Sarıyer & Fatih Sultan Mehmet (Armutlu) & 140,62 & Riskli alan \\
\hline 6306 & - & Silivri & Ortaköy & 0,31 & Rezerv Alan \\
\hline 6306 & - & Silivri & Piri Mehmetpaşa & 0,48 & Rezerv Alan \\
\hline 6306 & - & Silivri & Selimpaşa & 4,3 & Rezerv Alan \\
\hline 5393 & 2017 & Sultangazi & $\begin{array}{l}\text { Cumhuriyet, 50. Yıl, Esentepe } \\
\text { Kentsel Dönüşüm Gelişim Alanı }\end{array}$ & 32 & Kentsel dönüşüm ve gelişim alanı \\
\hline 6306 & - & Şişli & Kuştepe Kentsel Dönüşüm & 17 & - \\
\hline 6306 & 2013 & Tuzla & İçmeler & 6,78 & $\begin{array}{l}37 \text { adet bina, } 68 \text { konut II } 3 \text { ticari } \\
\text { birim olmak üzere toplam I8I } \\
\text { bağımsız bölüm }\end{array}$ \\
\hline 5366 & 2008 & Tuzla & Kamil Bey Gölü ve Çevresi & 188,90 & $\begin{array}{l}\text { Tuzla Kamil Bey Gölü ve Çevresi } \\
\text { Koruma Amaçlı Nazım Planı }\end{array}$ \\
\hline 5366 & 2006 & Tuzla & Köy içi Mevki 40 pafta & 10,89 & - \\
\hline 5366 & 2008 & Tuzla & Büyük Kü̈çük İçmeler Alanı & 11,58 & - \\
\hline 6306 & 2013 & Üsküdar & Burhaniye & $\mathrm{I}, 77$ & - \\
\hline 5393 & 2008 & Zeytinburnu & $\begin{array}{l}\text { Sümer Mahallesi Kentsel Dönüşüm } \\
\text { Alanı }\end{array}$ & 16 & $\begin{array}{l}\text { I } 36 \text { bina, I } 250 \text { bağımsız bölüm, \%35 } \\
\text { ruhsatsız yapı }\end{array}$ \\
\hline 5393 & 2018 & Zeytinburnu & $\begin{array}{l}\text { Çırpıcı ve Veliefendi Mahalleleri, } \\
\text { Kentsel Gelişim ve Dönüşüm Alanı }\end{array}$ & 5,15 & $\begin{array}{l}74 \text { bina, } 306 \text { bağımsız bölüm, \%59 } \\
\text { (44) ruhsatsız yapı }\end{array}$ \\
\hline 5366 & 2006 & Zeytinburnu & Yenileme Alanı & 240 & $\begin{array}{l}39 \text { tescilli anıt eser ve sivil mimari } \\
\text { örnek }\end{array}$ \\
\hline
\end{tabular}


Ek I (devamı). Bütünleştirilmiş tablo*

\begin{tabular}{|c|c|c|c|c|c|}
\hline $\begin{array}{l}\text { Yasa } \\
\text { numarası }\end{array}$ & $\begin{array}{l}\text { İlan } \\
\text { yılı }\end{array}$ & Bölge adı & Mahalle adı & $\begin{array}{l}\text { Büyüklük } \\
\text { (hektar) }\end{array}$ & $\begin{array}{l}\text { Mevcut } \\
\text { durum }\end{array}$ \\
\hline 6306 & 2016 & Zeytinburnu & Sümer Riskli Alan & 3,82 & $\begin{array}{l}\text { I } 36 \text { bina, I } 250 \text { bağımsız bölüm, \%35 } \\
\text { ruhsatsız yapı }\end{array}$ \\
\hline 6306 & 2017 & Zeytinburnu & Beştelsiz Mahallesi Riskli Alan & 0,5 & $\begin{array}{l}\text { I8 bina, I } 57 \text { bağımsız bölüm, \% I I } \\
\text { ruhsatsız yapı }\end{array}$ \\
\hline 6306 & 2017 & Zeytinburnu & Telsiz Mahallesi Riskli Alan & 0,8 & $\begin{array}{l}36 \text { bina, } 407 \text { bağımsız bölüm, \%5 } \\
\text { ruhsatsız yapı }\end{array}$ \\
\hline 6306 & 2017 & Zeytinburnu & Seyit Nizam Mahallesi Riskli Alan & 2,3 & II7 bina, \% 19 ruhsatsız yapı \\
\hline 6306 & 2017 & Zeytinburnu & Nakliyeciler Sitesi Riskli Alan & 15,6 & $\begin{array}{l}\text { Danıştay I4.Daire'nin } \\
\text { I I/06/20I8 tarihli ve E.20I7/826 } \\
\text { sayılı kararı ile iptal edilmiştir. }\end{array}$ \\
\hline 6306 & 2018 & Zeytinburnu & Nakliyeciler Sitesi Rezerv Alan & 16,1 & Boş \\
\hline 5393 & 2011 & Zeytinburnu & Sıvat Yeşiltepe & 54 & Büyük kısmı boş \\
\hline
\end{tabular}

*: Mevcut genel dönüşüm alanları farklı aşamalarda ve kapsamlı konular olması nedeniyle eksikliklerin olabileceği göz önünde bulundurulmalıdır. Kentsel dönüşüm sınırı iptal edilen veya kentsel dönüşüm kapsamından çıkarılan alanlar kalın yazılmıştır. 